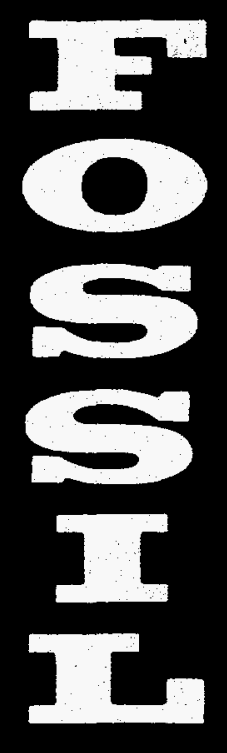

DOE/BCM-31-109-Eng-38-2 POE/BC- -97008692

(DE97008692)

COSTS FOR OFF-SITE DISPOSAL OF NONHAZARDOUS OIL FIELD WASTES: SALT CAVERNS VERSUS OTHER DISPOSAL METHODS

Topical Report

By

John A. Veil

$\mathcal{I}$

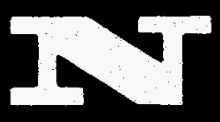

13
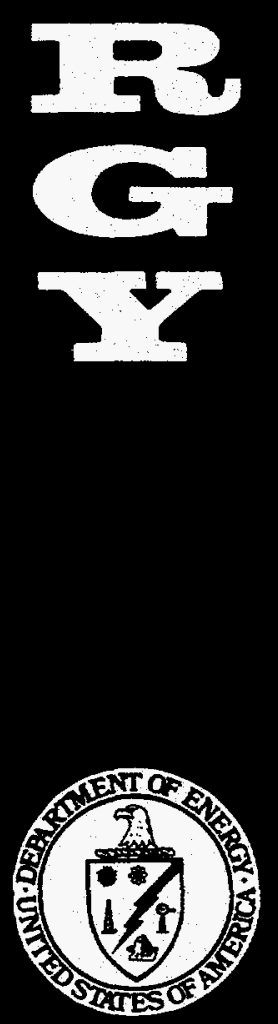

Argonne, IL
National Petroleum Technology Office U. S. DEPARTMENT OF ENERGY Tulsa, Oklahoma

\section{RECEIVED \\ OCT 161997 \\ OSTI}

September 1997

Performed Under Contract No. W-31-109-Eng-38

Argonne National Laboratory

Environmental Assessment Division

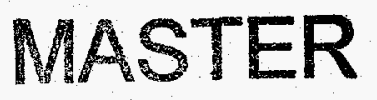


DISCLAIMER

This report was prepared as an account of work sponsored by an agency of the United States Government. Neither the United States Government nor any agency thereof, nor any of their employees, makes any warranty, expressed or implied, or assumes any legal liability or responsibility for the accuracy, completeness, or usefulness of any information, apparatus, product, or process disclosed, or represents that its use would not infringe privately owned rights. Reference herein to any specific commercial product, process, or service by trade name, trademark, manufacturer, or otherwise does not necessarily constitute or imply its endorsement, recommendation, or favoring by the United States Govemment or any agency thereof. The views and opinions of authors expressed herein do not necessarily state or reflect those of the United States Government.

This report has been reproduced directly from the best available copy.

Available to DOE and DOE contractors from the Office of Scientific and Technical Information, P.O. Box 62, Oak Ridge, TN 37831; prices available from (615) 5768401.

Available to the public from the National Technical. Information Service, U.S. Department of Commerce, 5285 Port Royal Rd., Springfield VA 22161 


$$
D O E / B C--970086092
$$

DOE/BCN-31-109-Eng-38-2

Distribution Category UC-122

Costs For Off-Site Disposal Of Nonhazardous Oil Field Wastes:

Salt Caverns Versus Other Disposal Methods

Topical Report

By

John A. Veil

September 1997

Work Performed Under Contract No. W-31-109-Eng-38

\author{
Prepared for \\ BDM-Oklahoma/ \\ U.S. Department of Energy \\ Assistant Secretary for Fossil Energy
}

Rhonda Lindsey, Project Manager

National Petroleum Technology Office

P.O. Box 3628

Tulsa, OK 74101

Prepared by:

Argonne National Laboratory

Environmental Assessment Division

9700 S. Cass Avenue

Argonne, IL 60439

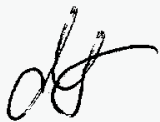




\section{DISCLAMMER}

Portions of this document may be illegible in electronic image products. Images are produced from the best available original document. 


\section{CONTENTS}

ACKNOWLEDGMENTS $\ldots \ldots \ldots \ldots \ldots \ldots \ldots \ldots \ldots \ldots \ldots \ldots \ldots \ldots \ldots \ldots$ vi

SUMMARY $\ldots \ldots \ldots \ldots \ldots \ldots \ldots \ldots \ldots \ldots \ldots \ldots \ldots \ldots \ldots \ldots \ldots \ldots \ldots$

1 INTRODUCTION $\ldots \ldots \ldots \ldots \ldots \ldots \ldots \ldots \ldots \ldots \ldots \ldots \ldots \ldots \ldots \ldots \ldots \ldots$

2 OIL FIELD WASTES AND DISPOSAL METHODS $\ldots \ldots \ldots \ldots \ldots \ldots \ldots \ldots$

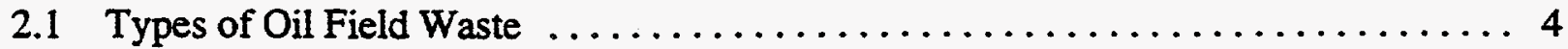

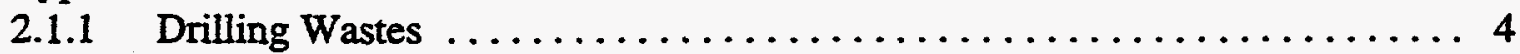

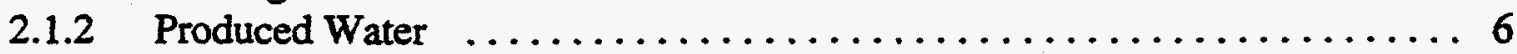

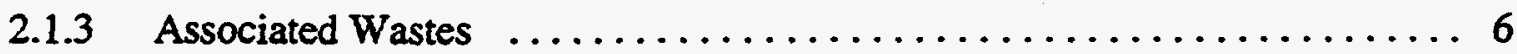

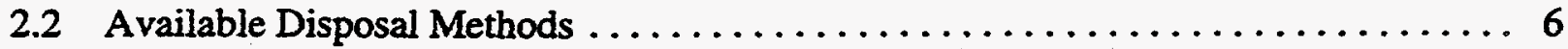

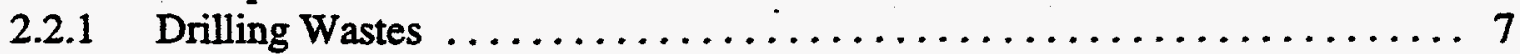

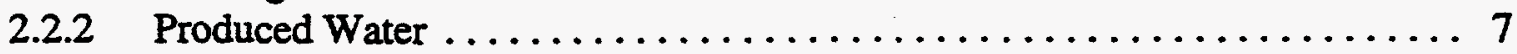

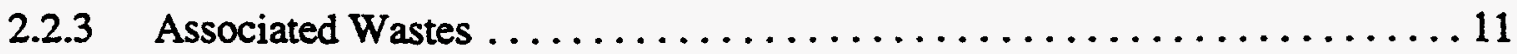

3 BACKGROUND ON SALT CAVERNS $\ldots \ldots \ldots \ldots \ldots \ldots \ldots \ldots \ldots \ldots \ldots \ldots$

3.1 Types and Locations of U.S. Subsurface Salt Deposits $\ldots \ldots \ldots \ldots \ldots \ldots \ldots$

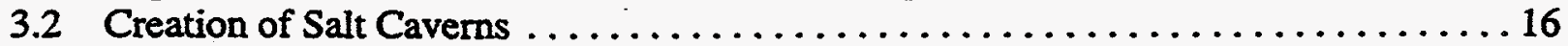

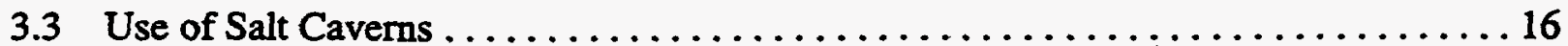

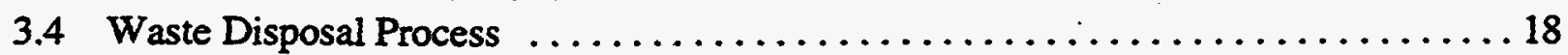

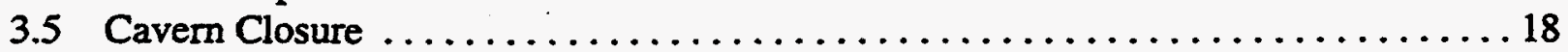

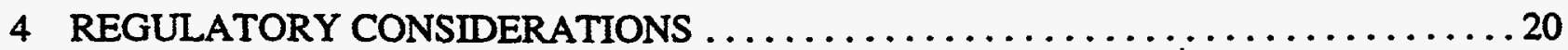

4.1 RCRA Exempts Oil Field Wastes from Hazardous Waste Requirements . . . . . . . 20

4.2 SDWA Regulates Salt Caverns for Oil Field Waste Disposal as

Class II Injection Wells . . . . . . . . . . . . . . . . . . . . . 20

4.3 CWA Regulates Discharges of Oil Field Wastes into Surface Water ... . . . . . 21

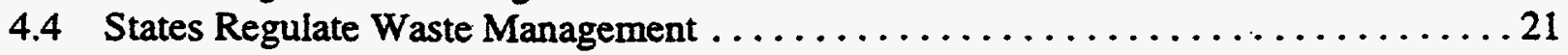

5 AVAILABILITY AND COST OF OFF-SITE COMMERCIAL DISPOSAL FACILITIES

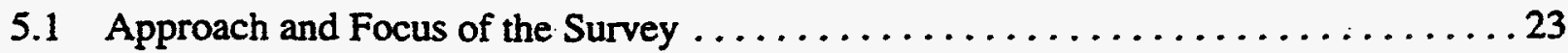

5.2 States with Industry-Specific Off-Site Commercial Disposal . . . . . . . . . . 24

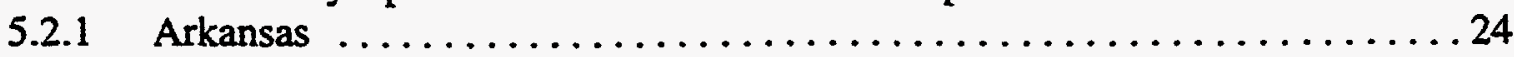

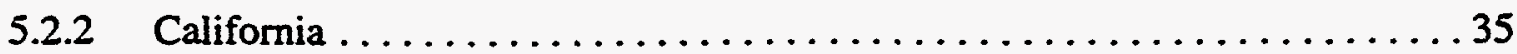

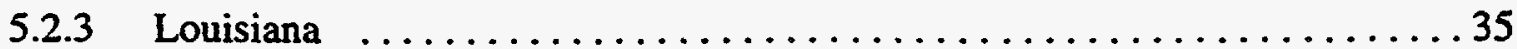

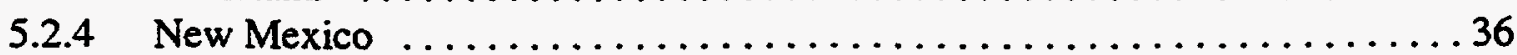




\section{CONTENTS}

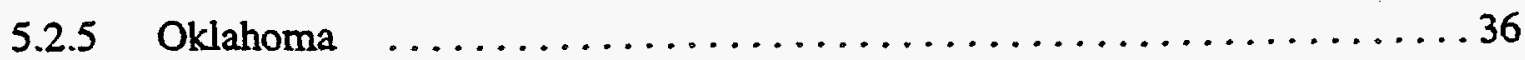

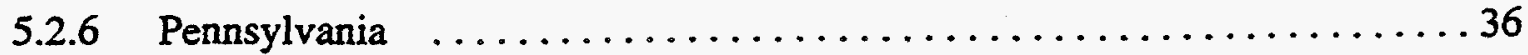

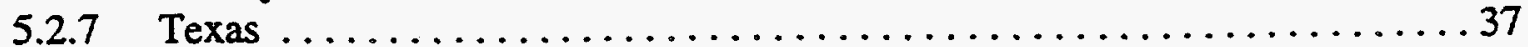

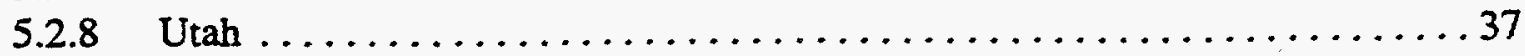

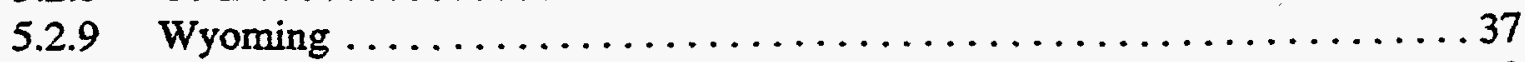

5.3 States without Industry-Specific Off-Site Comrnercial Disposal . . . . . . . . . 38

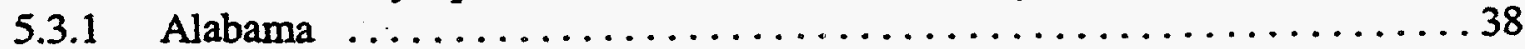

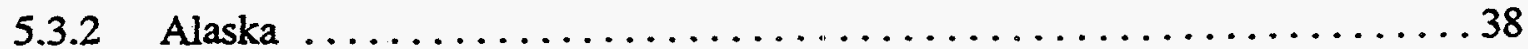

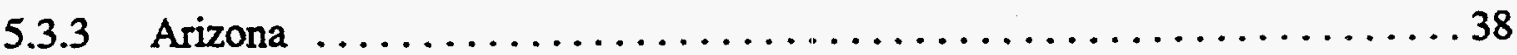

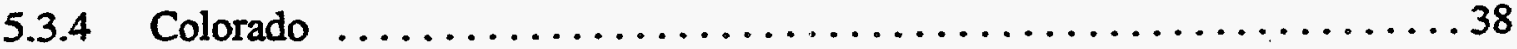

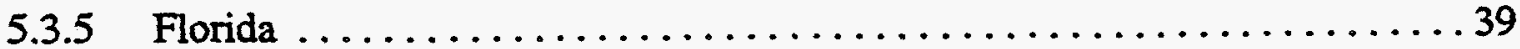

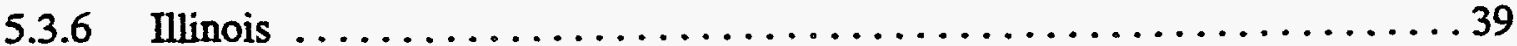

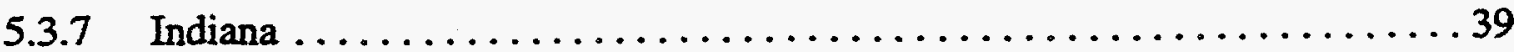

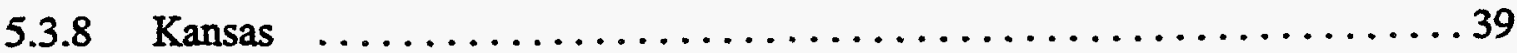

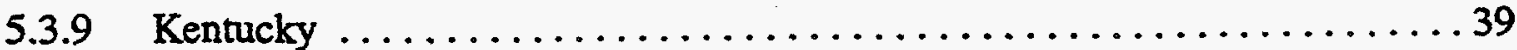

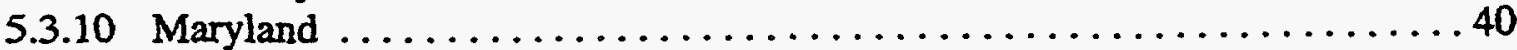

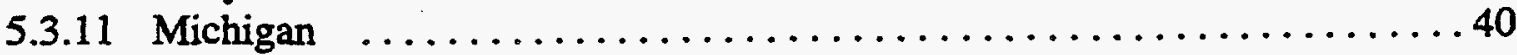

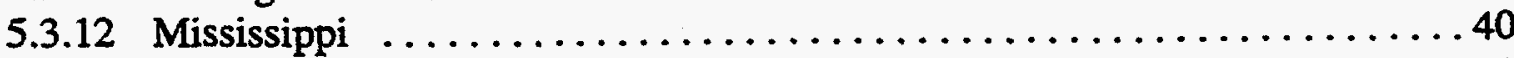

5.3 .13 Missouri ...................................... 41

5.3 .14 Montana ....................................... 41

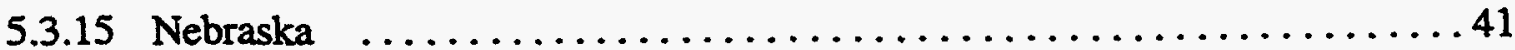

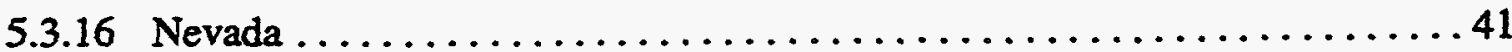

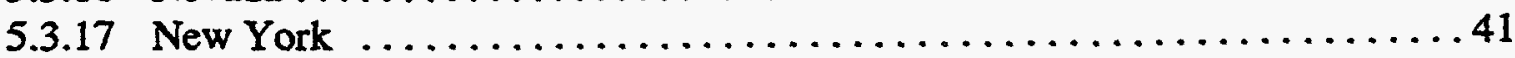

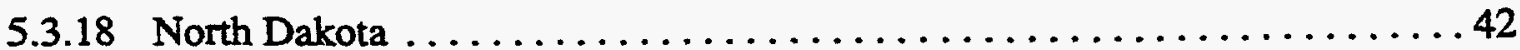

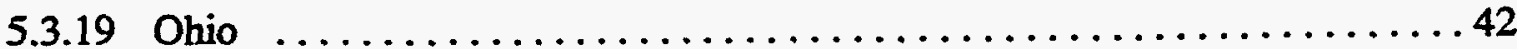

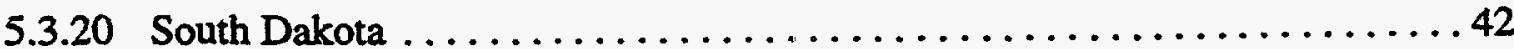

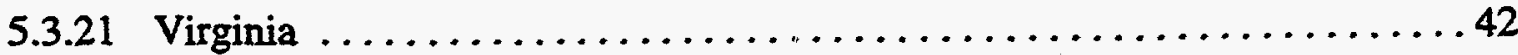

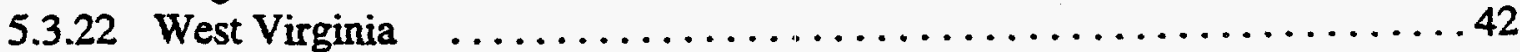

5.4 Costs of Off-Site Commercial Disposal $\ldots \ldots \ldots \ldots \ldots \ldots \ldots \ldots \ldots \ldots \ldots \ldots$

5.4 .1 Solid and Oily Waste ............................ 43

5.4.2 Produced Water, Including Rain Water and Other Water-Type Wastes ... 45

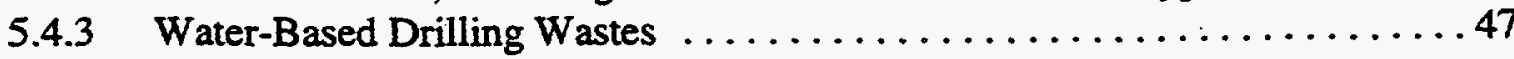

6 CONCLUSIONS .................................... 49

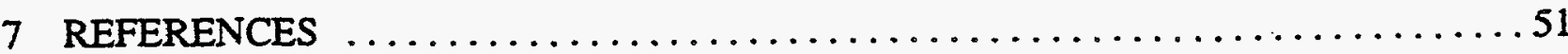




\section{TABLES}

1 Oil and Gas Wastes Exempted from RCRA Hazardous Waste Requirements ........ 5

2 Percentage of Drilling Waste Volumes for Each Disposal Method in 1985 Estimated in Wakim $(1987) \ldots \ldots \ldots \ldots \ldots \ldots \ldots \ldots \ldots \ldots$

3 Percentage of Drilling Waste Volumes for Each Disposal Method Estimated

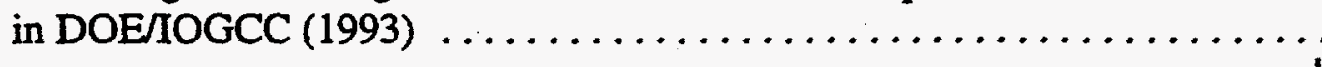

4 Percentage of Produced Water Volumes for Each Disposal Method

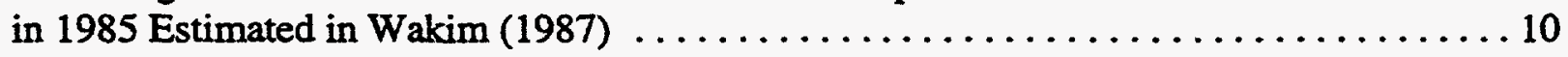

5 Percentage of Produced Water Volumes for Each Disposal Method Estimated

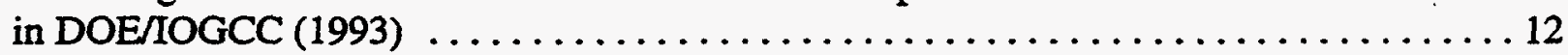

6 Percentage of Associated Waste Volumes for Each Disposal Method

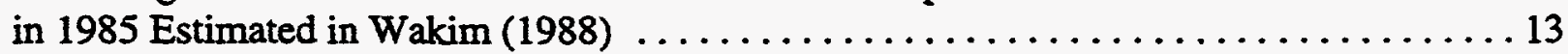

7 Percentage of Associated Waste Volumes for Each Disposal Method Estimated in DOEתIOGCC (1993) . . . . . . . . . . . . . . . . . . . . . . 14

8 Disposal Costs for Solid and Oily Nonhazardous Oil Field Wastes . . . . . . . . . . 25

9 Disposal Costs for Produced Water, Rain Water, and Other Water-Type Wastes . . . . . 29

10 Disposal Costs for Water-Based Drilling Wastes $\ldots \ldots \ldots \ldots \ldots \ldots \ldots \ldots \ldots$

\section{FIGURES}

1 Map Showing Major U.S. Rock Salt Deposits $\ldots \ldots \ldots \ldots \ldots \ldots \ldots \ldots \ldots \ldots$

2 Idealized Cavern in a Salt Dome Formation $\ldots \ldots \ldots \ldots \ldots \ldots \ldots \ldots \ldots$

3 Idealized Cavern in a Bedded Salt Formation $\ldots \ldots \ldots \ldots \ldots \ldots \ldots \ldots \ldots$

4 Locations of Disposal Caverns and Other Commercial Solid and Oily Waste Disposal Facilities within 75-Mile Radiuses 


\section{ACKNOWLEDGMENTS}

I wish to express appreciation for the assistance received from many state officials and commercial disposal company officials who participated in the survey described in this report. Their willingness to share technical and cost information enabled me to compile a meaningful database on commercial waste disposal methods and costs. I also acknowledge Nancy Johnson, U.S. Department of Energy, Office of Fossil Energy, without whose support and guidance the project would not have taken place. 


\title{
COSTS FOR OFF-SITE DISPOSAL OF NONHAZARDOUS OIL FIELD WASTES: SALT CAVERNS VERSUS OTHER DISPOSAL METHODS
}

\author{
by \\ John A. Veil \\ Argonne National Laboratory
}

SUMMARY

According to an American Petroleum Institute production waste survey reported on by P.G. Wakim in 1987 and 1988, the exploration and production segment of the U.S. oil and gas industry generated more than 360 million barrels (bbl) of drilling wastes, more than 20 billion bbl of produced water, and nearly 12 million bbl of associated wastes in 1985. Current exploration and production activities are believed to be generating comparable quantities of these oil field wastes. Wakim estimates that $28 \%$ of drilling wastes, less than $2 \%$ of produced water, and $52 \%$ of associated wastes are disposed of in off-site commercial facilities. In recent years, interest in disposing of oil field wastes in solution-mined salt caverns has been growing. This report provides information on the availability of commercial disposal companies in oil-and gas-producing states, the treatment and disposal methods they employ, and the amounts they charge. It also compares cavem disposal costs with the costs of other forms of waste disposal.

At the federal level, the majority of oil field wastes are considered to be exempt from the hazardous waste provisions of the Resource Conservation and Recovery Act (RCRA). These wastes are instead regulated at the state level. All oil- and gas-producing states allow some oil field wastes to be disposed of on-site. The commonly used on-site disposal methods include underground injection, on-site burial, land spreading or other land treatment, evaporation, surface discharge, and recycling. Argonne National Laboratory conducted interviews with oil and gas officials in 31 oiland gas-producing states to learn how oil field wastes are disposed of in their states and to identify commercial off-site disposal companies. Argonne then surveyed these disposal companies to learn what types of wastes they disposed of, what disposal methods they used, and how much they charged their customers.

There appear to be two major trends in off-site disposal. The first trend is exemplified in nine oil- and gas-producing states, where many commercial disposal companies are dedicated to handling oil field wastes. They use the same disposal methods as those used for on-site disposal. In addition, in one of these states - Texas - the Railroad Commission has issued permits to allow several salt caverns to be used for disposal of oil field wastes. The second trend is exemplified by 
22 other oil- and gas-producing states, where few or no companies are dedicated to disposing of oil and gas industry waste. The off-site commercial disposal companies available either handle only general industrial wastes or operate sanitary landfills.

In most cases, operators can dispose of their oil field wastes for a lower cost on-site than off-site; thus, they choose on-site disposal. In other cases, operators send their wastes off-site. The cost of off-site commercial disposal varies, depending on the disposal method used, the state in which the disposal company is located, and the degree of competition in the area. This report contains tables that provide cost data for disposing of three waste categories: (1) solid and oily wastes, which correspond to associated (small-volume wastes related to oil and gas exploration and production that are not drilling or water wastes) and oil-based drilling wastes; (2) produced water, rain water, and other types of dirty-water wastes; and (3) water-based drilling wastes. Disposal costs for solid and oily wastes range from $\$ 0$ to $\$ 57 / \mathrm{bbl}, \$ 6.50$ to $\$ 50 / \mathrm{yd}$, and $\$ 12$ to $\$ 150 /$ ton. Disposal costs for produced water, rain water, and other types of dirty-water wastes range from $\$ 0.01$ to $\$ 8 / \mathrm{bbl}$, although most costs fall in the $\$ 0.25$ to $\$ 1.50 / \mathrm{bbl}$ range. Disposal costs for water-based drilling wastes range from $\$ 0.20$ to $\$ 14.70 / \mathrm{bbl}, \$ 5$ to $\$ 37.50 / \mathrm{yd}$, and $\$ 15$ to $\$ 55 /$ ton.

Solution-mined salt cavern disposal costs are presently competitive in the Texas waste disposal market. However, they are likely to rise in the near future as the Railroad Commission of Texas adopts regulations governing cavem disposal. It is unclear how the increased costs will affect the competitiveness of these disposal caverns in the future, since costs for disposal at competing facilities will likely change. The use of commercial disposal caverns for oil field waste could spread to other states, but it will be limited by the availability of suitable salt formations and the size of the off-site commercial disposal market in those states. The market, in tum, is affected by the stringency of state regulations on disposing of oil field waste. Thus, future changes to state regulations on disposal of oil field waste will act as an a important catalyst to stimulate new cavern disposal operations. 


\section{INTRODUCTION}

As companies explore for and produce oil and gas, they generate various nonhazardous liquid, semisolid, and solid wastes. When on-site disposal of these wastes is allowed, it is generally the least expensive disposal option. Consequently, the majority of nonhazardous wastes are disposed of on-site. The term "on-site" includes waste disposal that occurs (1) on the same lease site as the one occupied by the oil and gas operation that generates the wastes and (2) at a location that is off the lease site but is owned or operated by the same company that operates the well that generates the wastes. Wastes are handled by off-site commercial disposal companies if state regulations preclude on-site disposal or if operators elect to avoid the responsibility of on-site waste disposal.

Works by Wakim $(1987,1988)$ summarize the results of a major, industrywide survey on waste production volumes and disposal methods conducted by the American Petroleum Institute (API) in 1985. Wakim (1987) found that more than 102 million barrels (bbl) or about $28 \%$ of drilling wastes and only a small fraction of produced water (less than $2 \%$ ) were disposed of off-site. Wakim (1988) found that more than 6 million bbl or about $52 \%$ of other wastes associated with oil and gas production were disposed of off-site. The Wakim studies provide good information on waste generation and disposal practices in the mid-1980s. To get more current information, API sent out a new waste management survey in the fall of 1996. Results are expected to be available in 1997.

Little information has been compiled on the number, location, type, and cost of commercial oil and gas waste disposal facilities. This report provides information on the commercial disposal options available to operators in selected oil- and gas-producing states. The costs of different disposal options are also provided.

Interest in using solution-mined salt caverns to dispose of oil field wastes has been growing. Recently, Argonne National Laboratory (ANL), under a U.S. Department of Energy (DOE) contract, evaluated the suitability, feasibility, and legality of disposing of nonhazardous oil field wastes in salt caverns (Veil et al. 1996). That report, which examined only solution-mined salt caverns and not excavated caverns, concluded that using salt caverns to dispose of oil field wastes is technically feasible and legal under both federal and state regulations. If caverns are well-sited and welldesigned, operated carefully, closed properly, and monitored routinely, they represent a suitable means of disposing of oil field wastes. ANL is also conducting a qualitative risk assessment of salt caverns used to dispose of nonhazardous oil field wastes. Because DOE has a continuing interest in exploring new and alternative waste disposal methods, especially those that are less costly or risky than existing methods, this report compares cavern disposal costs with the costs of other forms of waste disposal. 


\section{OIL FIELD WASTES AND DISPOSAL METHODS}

\subsection{TYPES OF OIL FIELD WASTE}

Most oil field wastes that arise from or are associated with oil and gas exploration and production are considered to be nonhazardous by virtue of being specifically exempted from federal hazardous waste requirements. A more detailed discussion of this subject is found in Section 4 . Table 1 is a list of oil field wastes exempted from the federal hazardous waste requirements of the Resource Conservation and Recovery Act (RCRA). These nonhazardous oil field wastes can be assigned to several categories: drilling wastes, produced water, and associated wastes. The categories are described below.

\subsubsection{Drilling Wastes}

Drilling wastes include drilling muds, drill cuttings, wash water, and other related wastes.

- Drilling muds are used in the drilling process to lubricate the drill bit, control wellbore pressure, and remove cuttings from the well. Mud systems can be freshwater-based (65\%), saltwater-based (23\%), oil-based $(3 \%)$, or other (Wakim 1987). Wakim found that in 1985 , drilling muds made up nearly $62 \%$ of drilling wastes.

- Drill cuttings are the particles of rock that are ground up by the drill bit during the drilling process. Cuttings are mixed with and covered with drilling muds. They made up about 10\% of the volume of drilling wastes (Wakim 1987).

- Water used to wash the drilling rig and for other drilling-related purposes made up about $24 \%$ of the volume of drilling wastes (Wakim 1987).

- Drilling wastes may contain oil and grease, inorganic salts; or other components of concern, depending on the type of mud system and additives used. These constituents can affect the way in which the wastes are disposed of. For example, most freshwater-based muds and cuttings are disposed of onsite, while oil-based muds may need to be sent off-site for disposal. 
TABLE 1 Oil and Gas Wastes Exempted from RCRA Hazardous Waste Requirements (53 FR 25446, July 6, 1988)

Produced water

Drilling fluids

Drill cuttings

Rigwash

Drilling fluids and cuttings from offshore operations disposed of onshore

Well completion, treatment, and stimulation fluids

Basic sediment and water and other tank bottoms from storage facilities that hold product and exempt waste

Accumulated materials, such as hydrocarbons, solids, sand, and emulsion from production separators, fluid treating vessels, and production impoundments

Pit sludges and contaminated bottoms from storage or disposal of exempt wastes

Workover wastes

Gas plant dehydration wastes, including glycol-based compounds, glycol filters, filter media, backwash, and molecular sieves

Gas plant sweetening wastes for sulfur removal, including amines, amine filters, amine filter media, backwash, precipitated amine sludge, iron sponge, and hydrogen sulfide scrubber liquid and sludge

Cooling tower blowdown

Spent filters, filter media, and backwash (assuming the filter itself is not hazardous and the residue in it is from an exempt waste stream

Packing fluids

Produced sand

Pipe scale, hydrocarbon solids, hydrates, and other deposits removed from piping and equipment prior to transportation

Hydrocarbon-bearing soil

Pigging wastes from gathering lines

Wastes from subsurface gas storage and retrieval

Constituents removed from produced water before it is injected or otherwise disposed of

Liquid hydrocarbons removed from the production stream but not from oil refining

Gases from the production stream, such as hydrogen sulfide and carbon dioxide, and volatilized hydrocarbons

Materials ejected from a producing well during the process known as blowdown

Waste crude oil from primary field operations and production

Light organics volatilized from exempt wastes in reserve pits or impoundments or production equipment 


\subsubsection{Produced Water}

Produced water is the water brought to the surface along with the oil and gas. It occurs naturally in the formations where oil and gas are found and is typically salty or brackish. The ratio of produced water to oil and gas increases over the life of the well. Produced water contains inorganic salts, oil and grease, and organics.

\subsubsection{Associated Wastes}

Associated wastes are small-volume wastes that are generated as a result of activities related to oil and gas exploration and production but are not dirilling wastes or produced water. Wakim (1988) estimated that in 1985, the U.S. oil and gas industry generated about 11.8 million bbl of associated wastes. Nearly half of that total (48\%) consisted of well treatment fluids (e.g., workover fluids, completion fluids). Other waste classes that contributed significantly to the volume of associated wastes include oil debris and contaminated soils (11\%), produced sands (11\%), and tank bottoms (10\%).

\subsection{AVAILABLE DISPOSAL METHODS}

Several methods to dispose of oil field wastes are available to operators. The most commonly used options are listed here:

- Underground injection (disposal wells, enhanced oil recovery wells, annular injection, salt caverns);

- On-site burial (pits, landfills);

- Land treatment (land spreading, land farming, road spreading);

- Evaporation;

- Surface discharge;

- Recycling; or

- Sending waste off-site for commercial disposal (the off-site facility would use one of the same methods as those used by the operator, as described above); 
Operators select a disposal option after considering the characteristics of the waste, federal and state regulations, and the availability and cost of commercial off-site disposal.

The following sections summarize information on disposal option preferences taken from Wakim's studies (1987 and 1988) and a more recent study sponsored by DOE and the Interstate Oil and Gas Compact Commission (DOE/IOGCC 1993). The data from DOE/IOGCC (1993) were not intended to be statistically representative of actual waste management practices but rather were determined on the basis of the best judgment of state regulators. Each study groups the potential disposal options somewhat differently, so the results cannot be exactly compared. Nevertheless, these studies provide a good indication of how operators disposed of wastes in the mid-1980s and early 1990 s.

\subsubsection{Drilling Wastes}

Wakim (1987) provides detailed information, by state, on the percentages of drilling wastes managed by means of different disposal methods. Table 2 summarizes these data. In the United States, $29 \%$ of drilling wastes were evaporated, $28 \%$ were hauled off-site to a commercial disposal facility, $13 \%$ were injected, $12 \%$ were buried on-site, $10 \%$ were discharged to surface waters, and $7 \%$ were land spread. Most states followed this trend, but in some states, one disposal method predominated (e.g., off-site burial in California, Michigan, and Ohio; land spreading in West Virginia; surface discharge in Arkansas; evaporation in Colorado, Kansas, and New Mexico; and annular injection in Alaska and Mississippi).

Table 3 is taken from DOE/IOGCC (1993). Since the table does not provide data for all states, no quantitative estimate of national disposal options selected in 1992 could be calculated. A qualitative analysis indicates that on-site burial was the most commonly selected option, with subsurface injection, land treatment, annular disposal, and off-site commercial disposal being selected in many other cases. Evaporation, the most commonly selected option found in Wakim (1987), was rarely used in the opinion of the state regulators surveyed by DOE/IOGCC (1993).

\subsubsection{Produced Water}

Table 4, which shows the proportion of produced water disposed of by means of different methods in 1985, is taken from Wakim (1987). The vast majority of produced water was injected; $62 \%$ was injected into enhanced oil recovery projects and $30 \%$ into disposal wells. About $6 \%$ of produced water was discharged to surface waters. In Louisiana, surface discharge was an important disposal mechanism. In California, $16 \%$ of produced water was disposed of by means of some other process, probably evaporation. 
TABLE 2 Percentage of Drilling Waste Volumes for Each Disposal Method in 1985 Estimated in Wakim (1987)

\begin{tabular}{|c|c|c|c|c|c|c|c|}
\hline State & $\begin{array}{l}\text { Off-Site } \\
\text { Disposal } \\
\end{array}$ & $\begin{array}{l}\text { Buried } \\
\text { On-Site }\end{array}$ & $\begin{array}{l}\text { Land } \\
\text { Spread }\end{array}$ & $\begin{array}{c}\text { Surface } \\
\text { Discharge }\end{array}$ & Evaporation & $\begin{array}{l}\text { Annular } \\
\text { Injection }\end{array}$ & Solidification \\
\hline Alabama & 28 & 10 & 5 & 13 & 30 & 14 & $\mathbf{0}$ \\
\hline Alaska & 18 & 13 & 0 & 18 & 0 & 51 & 0 \\
\hline Arkansas & 20 & 3 & 0 & 63 & 14 & 0 & 0 \\
\hline California & 75 & 17 & 1 & 0 & 5 & 0 & 2 \\
\hline Colorado & 17 & 18 & 0 & 13 & 51 & 0 & 0 \\
\hline Florida & 25 & 10 & 3 & 23 & 15 & 24 & 0 \\
\hline Illinois & 71 & 16 & 13 & 0 & 0 & 0 & 0 \\
\hline Indiana & 36 & 15 & 5 & 2 & 40 & 1 & 1 \\
\hline Kansas & 12 & 21 & 6 & 6 & 55 & 0 & 0 \\
\hline Kentucky & 39 & 9 & 5 & 2 & 43 & 2 & 1 \\
\hline Louisiana & 16 & 4 & 4 & 43 & 1 & 33 & 0 \\
\hline Michigan & 88 & 9 & 0 & 0 & 2 & 0 & 1 \\
\hline Mississippi & 1 & 6 & 0 & 17 & 1 & 75 & 0 \\
\hline Montana & 39 & 29 & 0 & 0 & 10 & 23 & 0 \\
\hline Nebraska & 23 & 18 & 8 & 6 & 42 & 3 & $\mathbf{1}$ \\
\hline Nevada & 29 & 10 & 6 & 7 & 35 & 13 & 0 \\
\hline New Mexico & 6 & 12 & 0 & 1 & 81 & 0 & 1 \\
\hline New York & 37 & 10 & 5 & 3 & 42 & 2 & 1 \\
\hline North Dakota & 55 & 22 & 0 & 1 & 19 & 2 & 0 \\
\hline Ohio & 84 & 15 & 0 & 0 & 1 & 0 & 0 \\
\hline Oklahoma & 43 & 16 & 0 & 0 & 30 & 11 & 0 \\
\hline Pennsylvania & 57 & 17 & 0 & 14 & 5 & 7 & 0 \\
\hline Texas & 25 & 11 & 13 & 2 & 39 & 10 & 0 \\
\hline Utah & 39 & 14 & 0 & 11 & 34 & 2 & 0 \\
\hline West Virginia & 3 & 12 & 77 & 8 & 0 & 0 & 0 \\
\hline Wyoming & 36 & 15 & 0 & 2 & 44 & 3 & 0 \\
\hline Total ${ }^{\mathrm{a}}$ & 28 & 12 & 7 & 10 & 29 & 13 & 0 \\
\hline
\end{tabular}

a Tolal also includes minor contributions from several other states not shown. 
TABLE 3 Percentage of Drilling Waste Volumes for Each Disposal Method Estimated in DOE/IOGCC (1993) ${ }^{\mathrm{a}}$

\begin{tabular}{|c|c|c|c|c|c|c|c|}
\hline State & $\begin{array}{l}\text { Off-Site } \\
\text { Disposal }\end{array}$ & $\begin{array}{l}\text { Buried } \\
\text { On-Site }\end{array}$ & Land Spread & $\begin{array}{l}\text { Surface } \\
\text { Discharge }\end{array}$ & Evaporation & $\begin{array}{c}\text { Annular and } \\
\text { Subsurface Injection }\end{array}$ & $\begin{array}{l}\text { Recycling/Closed } \\
\text { Drilling System }\end{array}$ \\
\hline Alabama & c & & & & & c & c \\
\hline California & c & c & c & c & & c & c \\
\hline Colorado & c & $\mathrm{c}$ & c & & c & & c \\
\hline Kansas & 20 & 75 & & & 3 & 1 & 1 \\
\hline Louisiana & 22 & & 51 & & & 27 & c \\
\hline Michigan & & 65 & & & 3 & 32 & c \\
\hline Mississippi & & & c & 50 & & $\mathrm{c}$ & c \\
\hline Montana & c & 75.85 & c & & c & c & c \\
\hline New Mexico & & c & c & & & & c \\
\hline North Dakota & 3 & 42 & & & & 54 & 1 \\
\hline Ohio & $3-4$ & $27-36$ & & & & $60-70$ & $<1$ \\
\hline Oklahoma & 54 & & 12 & & & 33 & c \\
\hline Pennsylvania & $<1$ & 60 & 38 & $<1$ & & & $<1$ \\
\hline Texas & 2 & 83 & $<4$ & $<0.5$ & & 11 & \\
\hline Utah & c & c & & & & & \\
\hline West Virginia & 3 & 13 & 77 & 7 & & & \\
\hline Wyoming & c & c & c & & & c & 5 \\
\hline
\end{tabular}

a Based on best judgment of state regulators.

b DOE/lOGCC (1993) provides separate categories for subsurface injection and annular injection but provides no explanation for that distinction; both categories are combined here.

c Indicated practice is allowable and may be used in the state; no other data are available. 
TABLE 4 Percentage of Produced Water Volumes for Each Disposal Method in 1985 Estimated in Wakim (1987)

\begin{tabular}{|c|c|c|c|c|}
\hline State & $\begin{array}{l}\text { Disposal } \\
\text { Wells }\end{array}$ & $\begin{array}{c}\text { Enhanced Oil } \\
\text { Recovery }\end{array}$ & $\begin{array}{c}\text { Surface } \\
\text { Discharge }\end{array}$ & Other \\
\hline Alabama & 85 & 15 & 0 & 0 \\
\hline Alaska & 29 & 71 & 0 & 0 \\
\hline Arkansas & 46 & 54 & 0 & 0 \\
\hline California & 23 & 54 & 6 & 16 \\
\hline Colorado & 8 & 92 & 0 & 0 \\
\hline Illinois & 5 & 95 & 0 & 0 \\
\hline Kansas & 60 & 39 & 0 & 0 \\
\hline Kentucky & 100 & 0 & 0 & 0 \\
\hline Louisiana & 46 & 10 & 44 & 1 \\
\hline Michigan & 35 & 65 & 0 & 0 \\
\hline Mississippi & 96 & 4 & 0 & 0 \\
\hline Montana . & 16 & 83 & 1 & 0 \\
\hline Nebraska & 60 & 39 & 0 & 1 \\
\hline New Mexico & 17 & 83 & 0 & 0 \\
\hline North Dakota & 72 & 28 & 0 & 0 \\
\hline Oklahoma & 9 & 91 & 0 & 0 \\
\hline Texas & 31 & 64 & 3 & 2 \\
\hline Utah & 36 & 63 & 1 & 0 \\
\hline West Virginia & 100 & 0 & 0 & 0 \\
\hline Wyoming & 55 & 28 & 17 & 0 \\
\hline Total $^{a}$ & 30 & 62 & 6 & 3 \\
\hline
\end{tabular}

a Total also includes minor contributions from several other states not shown. 
Results shown in Table 5, taken from DOE/IOGCC (1993), are very similar to those shown in Table 4. In most states, a high percentage of produced water was reinjected. Several states discharged a significant quantity of produced water to surface waters, although the volume of produced water discharged to surface waters is declining. In California, an estimated $20 \%$ of produced water was evaporated.

\subsubsection{Associated Wastes}

Table 6, which shows the proportion of associated wastes disposed of by means of different methods in 1985, is taken from Wakim (1988). Nationally, more than half of the associated waste (52\%) was taken to off-site commercial facilities, $14 \%$ was spread on roads, $9 \%$ was land spread, $7 \%$ was recycled, $7 \%$ was injected, and $5 \%$ was buried on-site. States showed substantial variation in their use of the most commonly selected options.

Table 7, which lists data from DOE/IOGCC (1993) on disposal of associated wastes, reveals no clear trends. Subsurface injection, commercial off-site disposal, land treatment, and onsite burial all are used to dispose of more than $95 \%$ of the associated wastes in at least one state. 
TABLE 5 Percentage of Produced Water Volumes for Each Disposal Method Estimated in DOE/IOGCC (1993)

\begin{tabular}{|c|c|c|c|c|c|c|c|c|}
\hline State & $\begin{array}{c}\text { Disposal } \\
\text { Wells }\end{array}$ & $\begin{array}{c}\text { Enhanced Oil } \\
\text { Recovery }\end{array}$ & $\begin{array}{c}\text { Surface } \\
\text { Discharge }\end{array}$ & Evaporation & $\begin{array}{l}\text { Off-Site } \\
\text { Disposal }\end{array}$ & $\begin{array}{l}\text { Annular } \\
\text { Injection }\end{array}$ & $\begin{array}{c}\text { Road } \\
\text { Spreading }\end{array}$ & Other \\
\hline Alabama, oil/conventional gas & & & & & & & & b \\
\hline Alabama, coalbed methane gas & b & & b & & & & & $\mathbf{b}$ \\
\hline California & 25 & 32 & 9 & 20 & & & & 14 \\
\hline Colorado & & & b & b & $\mathbf{b}$ & & & b \\
\hline Kansas & 60 & 39 & & & & & $<1$ & \\
\hline Louisiana & 46 & 8 & 44 & & & 2 & & \\
\hline Michigan & 63 & 37 & & & & & $<1$ & \\
\hline Mississippi & b & b & & & & $\mathbf{b}$ & & \\
\hline Montana & 16 & 83 & $<1$ & $<1$ & & & & \\
\hline New Mexico & & & $\mathbf{b}$ & b & & & & \\
\hline North Dakota & 72 & 28 & & & & & & \\
\hline Ohio & & & & & & 2 & 4 & \\
\hline Oklahoma & 28 & 72 & $<1$ & & & & & \\
\hline Pennsylvania & b & b & $\mathbf{b}$ & & $\mathbf{b}$ & & b & b \\
\hline Texas & 37 & 61 & 1.6 & 0.2 & 0.2 & & & \\
\hline Utah & 22 & 51 & 25 & 2 & & & & \\
\hline \multicolumn{9}{|l|}{ West Virginia } \\
\hline Wyoming & 9 & 58 & 31 & 2 & & & & \\
\hline
\end{tabular}

a Based on best judgment of state regulators.

b Indicated practice is allowable and may be used in the state; no other data are available. 
TABLE 6 Percentage of Associated Waste Volumes for Each Disposal Method in 1985 Estimated in Wakim (1988)

\begin{tabular}{|c|c|c|c|c|c|c|c|c|c|}
\hline State & $\begin{array}{l}\text { Off-Site } \\
\text { Disposal }\end{array}$ & $\begin{array}{l}\text { Buried } \\
\text { On-Site }\end{array}$ & Land Spread & $\begin{array}{c}\text { Surface } \\
\text { Discharge }\end{array}$ & Evaporation & $\begin{array}{l}\text { Annular } \\
\text { Injection }\end{array}$ & Recycled & $\begin{array}{c}\text { Road } \\
\text { Spreading }\end{array}$ & Other \\
\hline Alabama & 1 & 3 & 2 & 0 & 10 & 41 & 38 & 2 & 2 \\
\hline Alaska & 19 & 0 & 0 & 0 & 12 & 69 & 0 & 0 & 0 \\
\hline Arkansas & 13 & 9 & 2 & 1 & 8 & 13 & 45 & 10 & 0 \\
\hline California & 40 & 0 & 5 & 0 & 1 & 0 & 2 & 51 & 1 \\
\hline Colorado & 4 & 45 & 0 & 0 & 1 & 46 & 2 & 2 & 1 \\
\hline Florida & 94 & 0 & 0 & 0 & 2 & 0 & 4 & 0 & 0 \\
\hline Illinois & 1 & 0 & 16 & 0 & 0 & 0 & 65 & 18 & 0 \\
\hline Kansas & 21 & 19 & 1 & 0 & 5 & 3 & 15 & 37 & 0 \\
\hline Louisiana & 59 & 1 & 0 & 4 & 10 & 1 & 20 & 1 & 4 \\
\hline Michigan & 85 & 0 & 0 & 0 & 2 & 7 & 5 & 0 & 1 \\
\hline Mississippi & 3 & 3 & 1 & 0 & 15 & 8 & 68 & 1 & 0 \\
\hline Montana & 97 & 2 & 0 & 0 & 0 & 0 & 0 & 0 & 0 \\
\hline Nebraska & 75 & 5 & 0 & 0 & 1 & 1 & 5 & 11 & 0 \\
\hline New Mexico & 94 & 1 & 0 & 0 & 1 & 1 & 4 & 0 & 0 \\
\hline North Dakota & 98 & 0 & 0 & 0 & 0 & 0 & 2 & 0 & 0 \\
\hline Oklahoma & 69 & 2 & 0 & 2 & 2 & 11 & 4 & 2 & 7 \\
\hline Texas & 57 & 3 & 17 & 0 & 5 & 1 & 9 & 5 & 2 \\
\hline Utah & 33 & 14 & 9 & 0 & 31 & 1 & 7 & 0 & 5 \\
\hline West Virginia & 1 & 0 & 97 & 0 & 2 & 0 & 1 & 0 & 0 \\
\hline Wyoming & 39 & 5 & 1 & 0 & 28 & 0 & 23 & 6 & 2 \\
\hline Total $^{a}$ & 52 & 5 & 9 & 1 & 3 & 7 & 7 & 14 & 2 \\
\hline
\end{tabular}

a Total also includes minor contributions from several other states not shown. 
TABLE 7 Percentage of Associated Waste Volumes for Each Disposal Method Estimated in DOE/IOGCC (1993) ${ }^{\mathrm{a}}$

\begin{tabular}{|c|c|c|c|c|c|c|c|c|}
\hline State & $\begin{array}{c}\text { Off-Site } \\
\text { Disposal }\end{array}$ & $\begin{array}{l}\text { Buried } \\
\text { On-Site }\end{array}$ & $\begin{array}{l}\text { Land } \\
\text { Spread }\end{array}$ & $\begin{array}{c}\text { Surface } \\
\text { Discharge }\end{array}$ & $\begin{array}{l}\text { Subsurface } \\
\text { Injection }\end{array}$ & Recycled & $\begin{array}{c}\text { Road } \\
\text { Spreading } \\
\end{array}$ & Other \\
\hline Alabama & b & & & & b & & & \\
\hline California & b & & . & & b & & & \\
\hline Colorado & $\mathbf{b}$ & & 95 & & $\mathbf{b}$ & & & \\
\hline Kansas & 17 & 30 & & & 1 & 20 & 32 & \\
\hline Louisiana & $\mathbf{b}$ & & & & & & & \\
\hline Michigan & 97 & & & & & 3 & & \\
\hline Mississippi & 100 & & & $\mathbf{b}$ & $\mathbf{b}$ & & b & b \\
\hline Montana & b & $>50$ & $\mathbf{b}$ & & & 7 & 5 & \\
\hline New Mexico & & $\mathbf{b}$ & b & & b & b & & $\mathbf{b}$ \\
\hline North Dakota & b & & & & & 20 & & \\
\hline Ohio & $\mathbf{b}$ & $90-95$ & & & $\mathbf{b}$ & & & \\
\hline Oklahoma & $>80$ & b & b & & b & 3 & b & \\
\hline Pennsylvania & b & b & b & & & & & b \\
\hline \multicolumn{9}{|l|}{ Texas } \\
\hline Workover/completion wastes & & 5 & & & 95 & & & \\
\hline Basic sediments & $!$ & 93 & 1 & & & & 5 & \\
\hline Other oily wastes & 1 & 1 & 97 & & 1 & & & \\
\hline Utah & $\mathbf{b}$ & 20 & & & & b & & \\
\hline West Virginia & 42 & 18 & & & & 40 & & \\
\hline Wyoming & \multicolumn{8}{|c|}{$24 \%$ is recycled; of the remaining volume, $90 \%$ is disposed of on-site and $10 \%$ is disposed of off-site. } \\
\hline
\end{tabular}

a Based on best judgment of state regulators.

b Indicated practice is allowable and may be used in the state; no other data are available. 


\section{BACKGROUND ON SALT CAVERNS}

Veil et al. (1996) discusses many aspects of salt formations and salt caverns. Relevant portions of that information are summarized in this section. Both Veil et al. (1996) and this report consider only solution-mined salt caverns. Underground chambers or caverns can also be formed in salt deposits through room-and-pillar mining, which involves mechanical excavation of the salt deposits. To the author's knowledge, only solution-mined caverns have been proposed for use as disposal caverns for nonhazardous oil and gas wastes. Room-and-pillar mining is not discussed further in this report.

\subsection{TYPES AND LOCATIONS OF U.S. SUBSURFACE SALT DEPOSITS}

Figure 1 (redrawn from Johnson and Gonzales 1978) shows the locations of the major. U.S. subsurface salt deposits. There are two types of subsurface salt deposits in the United States: salt domes and bedded salt. Salt domes are large, generally homogeneous formations of salt that are

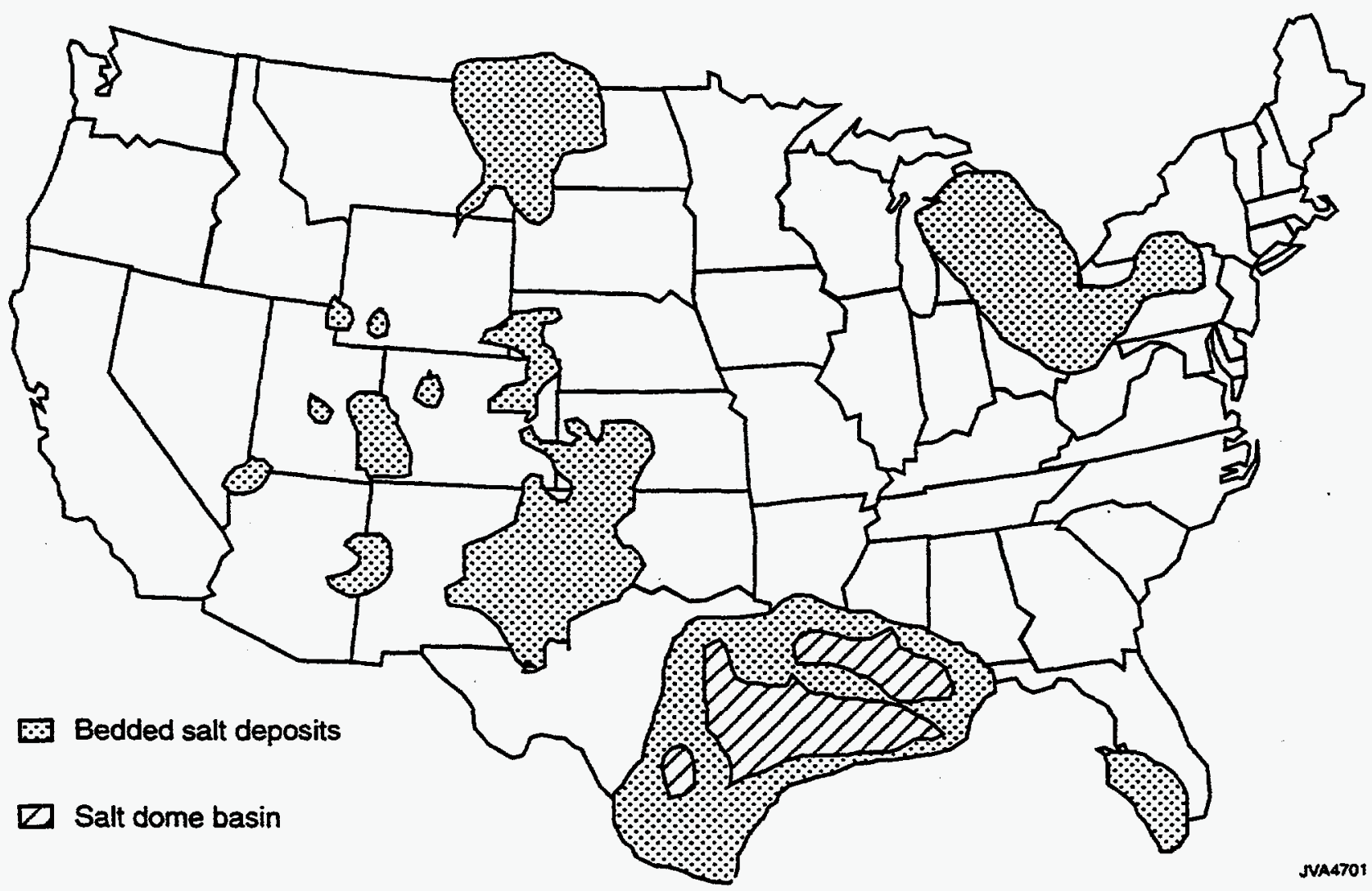

FIGURE 1 Map Showing Major U.S. Rock Salt Deposits 
formed when a column of salt migrates upward from a deep salt bed, passing through the overlying sediments. Salt dome deposits are found in the Gulf Coast region of Texas, Louisiana, Mississippi, and Alabama.

Bedded salt formations occur in layers bounded on the top and bottom by impermeable formations and are interspersed with nonsalt, sedimentary materials having varying levels of impermeability, such as anhydrite, shale, and dolomite. Unlike salt domes, which are large masses of relatively pure sodium chloride, bedded salt deposits are tabular deposits of sodium chloride that can contain significant quantities of impurities. Major bedded salt deposits occur in several parts of the United States.

Although salt deposits occur in many parts of the United States, in most states, the occurrence of salt in the quantities and locations that would promote commercial mining is very limited. There are 16 states in which salt occurs in sufficient quantity to be mined by either excavation, solution mining, or solar evaporation: Alabama, Arizona, Colorado, Kansas, Louisiana, Michigan, Mississippi, Montana, New Mexico, New York, North Dakota, Ohio, Oklahoma, Pennsylvania, Texas, and Utah.

Of the states listed above, Kansas, Louisiana, Michigan, New Mexico, New York, Ohio, and Texas have the most significant salt mining operations. These states either now contain or have the potential to contain a cavern suitable for oil and gas waste disposal. Pennsylvania contains caverns that are currently permitted for hydrocarbon storage but could be converted to waste disposal caverns. Utah has some potential for future disposal cavern operations, although it is a relatively small oil and gas waste generator. The remaining states have only a limited number of salt production sites and are not likely candidates for future cavern storage operations.

\subsection{CREATION OF SALT CAVERNS}

Salt caverns are created by injecting fresh water into a salt formation and withdrawing the resulting brine solution. Figures 2 and 3 show the idealized construction for caverns in domal salt and bedded salt, respectively. The petroleum industry has constructed many salt caverns to store hydrocarbons. To provide guidance for designing and operating hydrocarbon storage salt cavems, several organizations have developed standards documents (CSA 1993; API 1994; IOGCC 1995). Details on the design, location, and construction of salt caverns are provided in these reports.

\subsection{USE OF SALT CAVERNS}

The most common use for salt caverns is to store hydrocarbons such as propane, butane, ethane, ethylene, fuel oil, gasoline, natural gas, and crude oil (Querio 1980). In 1975, the 


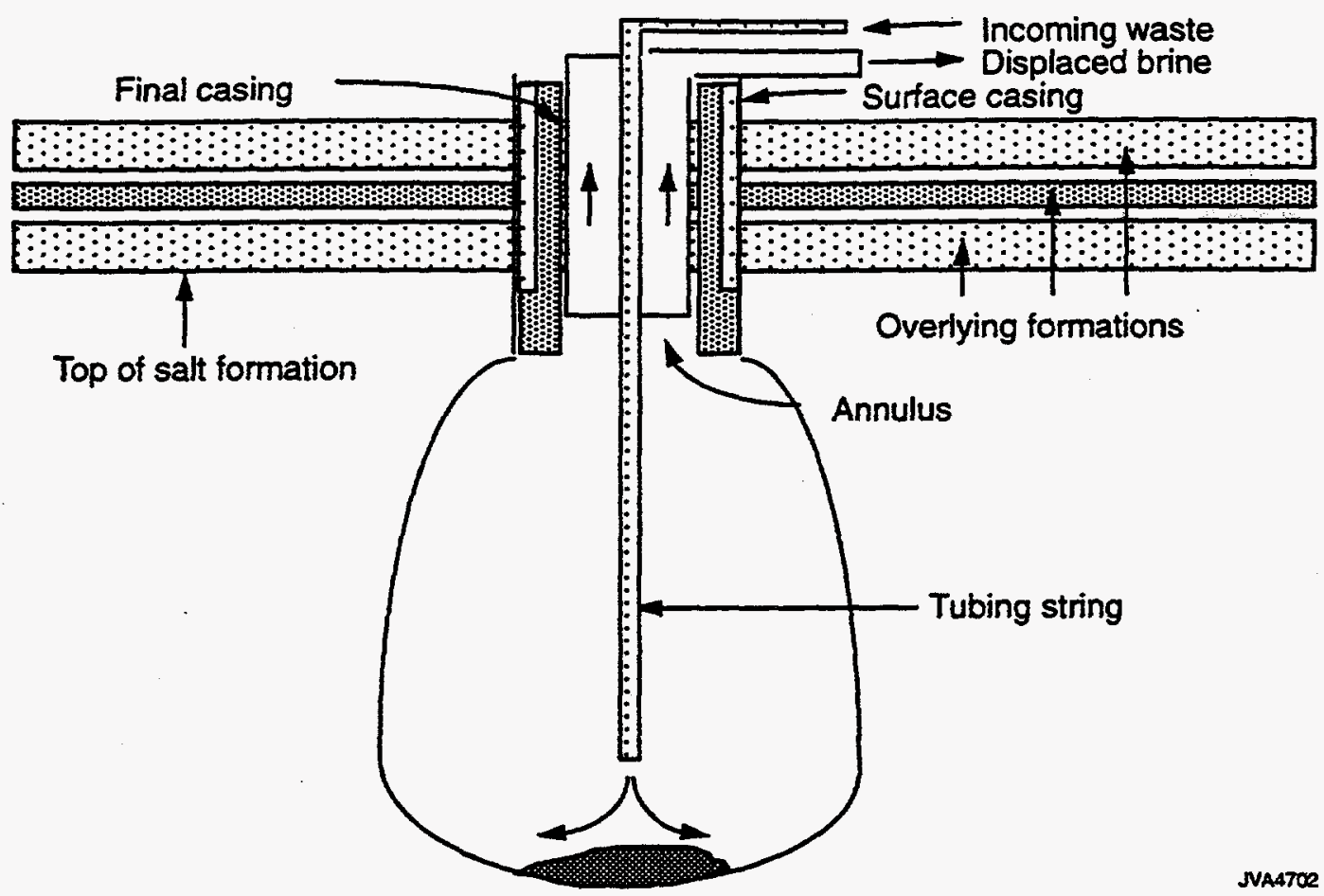

FIGURE 2 Idealized Cavern in a Salt Dome Formation

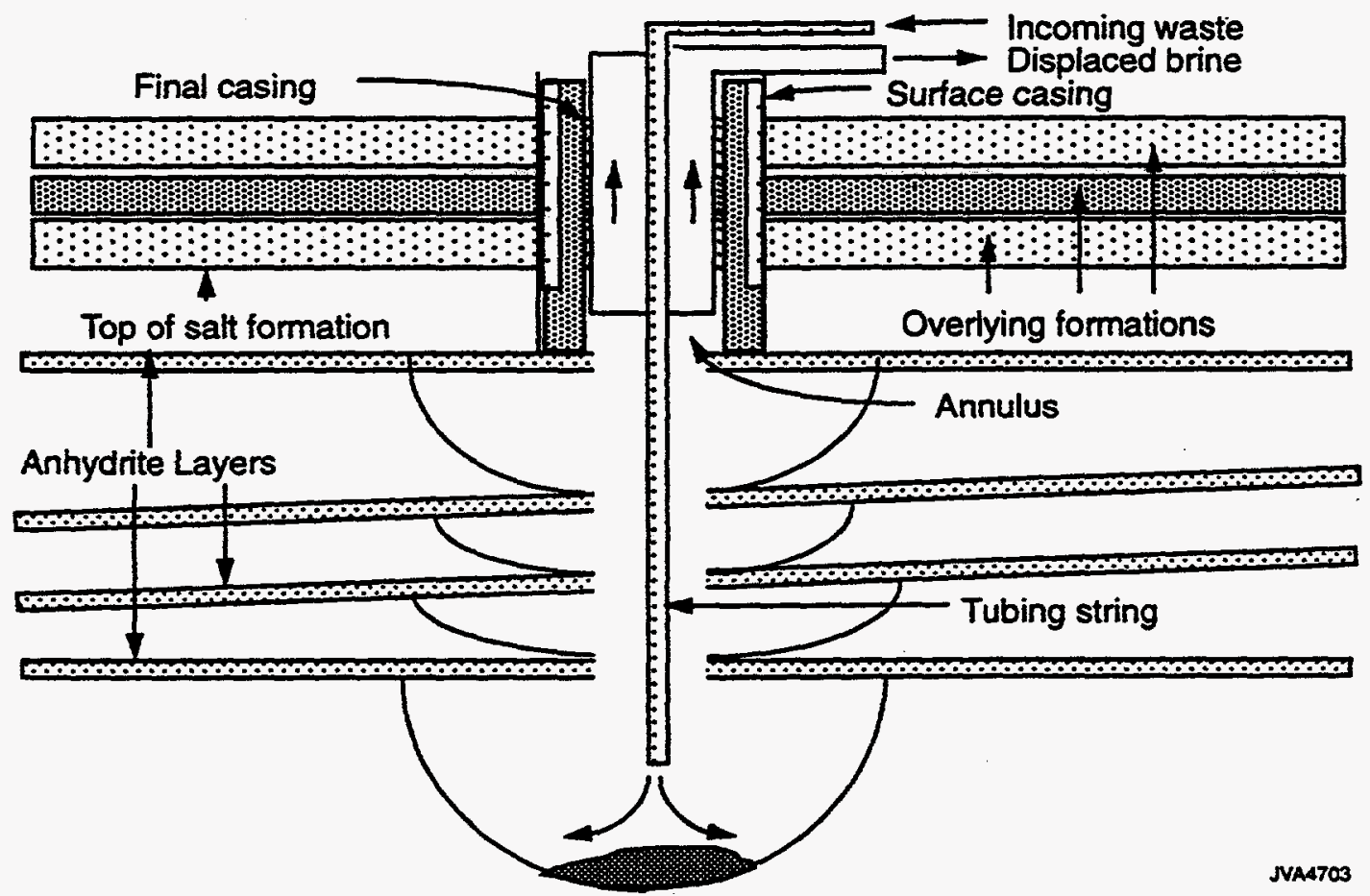

FIGURE 3 Idealized Cavern in a Bedded Salt Formation 
U.S. Congress created the Strategic Petroleum Reserve (SPR) program to provide the country with sufficient petroleum reserves to reduce any impacts that might be caused by future interruptions in the oil supply. The SPR consists of 62 leached caverns in domal salt with a total capacity of 680 million bbl. DOE has prepared a plan for, but is not currently pursuing, the development of an additional 250 million bbl of storage capacity. Highly compressed air has also been stored in some caverns, where it can later be withdrawn to generate electricity.

A second use for salt caverns is to dispose of various wastes. In the United States and other countries, only a limited number of salt caverns have been issued permits for waste disposal. The Railroad Commission of Texas has issued permits for disposal of nonhazardous oil field waste in six caverns. Four of these are presently operating as disposal caverns. At least two caverns in Canada have been permitted for disposal of nonhazardous oil field waste. Veil et al. (1996) describes other types of cavern disposal activities in the United Kingdom, Germany, the Netherlands, and Mexico.

\subsection{WASTE DISPOSAL PROCESS}

Initially, caverns are filled with clean brine. Wastes are introduced as a slurry of waste and a carrier fluid (brine or fresh water). A carrier fluid that is not fully saturated with salt will eventually leach salt from the cavern walls or roof. Expansion of cavern diameter is generally not a problem as long as the anticipated degree of expansion is accounted for in the cavern design and the actual degree of expansion is monitored throughout the waste emplacement cycle. To avoid excessive leaching of the cavern roof, operators may intentionally introduce a hydrocarbon pad that, by virtue of its lower density, will float to the top of the cavern and keep the unsaturated carrier fluid from coming in contact with the cavern roof.

As the waste slurry is injected, the cavern acts as an oil/water/solids separator. The heavier solids fall to the bottom of the cavern, forming a pile. Any free oils or hydrocarbons that are associated with the waste float to the top of the cavern. Clean brine displaced by the incoming slurry is removed from the cavern and either sold as a product or disposed of in an injection well. When the cavern is filled, the operator removes the hydrocarbon pad and plugs the cavern.

\subsection{CAVERN CLOSURE}

There is no actual field experience on the long-term impacts from disposing of oil field wastes in salt caverns. Theoretical studies estimate what might happen after such a cavem is closed. Various authors agree that pressures will build up in a closed cavern because of salt creep and geothermal heating. However, these authors do not specifically address caverns filled with oil field wastes. Several experienced researchers in the field interviewed by the authors of Veil et al. (1996) believe that caverns filled with oil field wastes would be much less likely to leak than would caverns 
filled with less dense liquids. However, other experienced researchers believe that until the pore space of the waste pile is reduced through creep-induced compaction, a solids-filled cavern will behave in the same way as a fluid-filled cavern.

Some disposal caverns might leak after closure because of elevated pressures; however, the time needed for pressures to build to the point of cavern failure is not defined. Argonne's risk assessment of disposal caverns, due to be completed in late 1997, may shed some light on the consequences of cavern failure. Additional research on the likelihood and rates of cavern failure following closure would be useful to better understand this issue. 


\section{REGULATORY CONSIDERATIONS}

This section describes the federal and state requirements that apply to the disposal of oil field wastes. Three federal statutes govern disposal of oil field wastes - the Resource Conservation and Recovery Act (RCRA), Safe Drinking Water Act (SDWA), and Clean Water Act (CWA).

\subsection{RCRA EXEMPTS OIL FIELD WASTES FROM HAZARDOUS WASTE REQUIREMENTS}

The most important distinction between oil field wastes and many other types of industrial wastes is that the former are exempted from the hazardous waste requirements of RCRA. On July 6, 1988, the U.S. Environmental Protection Agency (EPA) issued a regulatory determination that exempted any wastes arising from the exploration, development, and production of crude oil, natural gas, and geothermal energy from regulation as hazardous wastes under RCRA Subtitle $C$ (53 FR 25477). The list of wastes exempted from RCRA Subtitle C is reproduced in Table 1. On March 22, 1993, the EPA clarified the 1988 determination and exempted many other wastes that were uniquely associated with exploration and production operations from RCRA Subtitle C requirements (58 FR 15284). The clarification restates the EPA's position that wastes derived from treatment of an exempted waste generally remain exempt, and that off-site transportation does not negate the exemption. Some wastes derived from treatment of an exempt waste may not be exempt, however.

The EPA has emphasized the need to work with states to encourage changes in their regulations to improve the management of wastes from oil and gas exploration and production. Given the federal exemption from RCRA for oil field wastes, the waste management requirements faced by most operators will be state requirements.

\subsection{SDWA REGULATES SALT CAVERNS FOR OIL FIELD WASTE DISPOSAL AS CLASS II INJECTION WELLS}

Unlike most other methods for disposing of nonhazardous oil field waste, salt caverns and injection wells are subject to the requirements of the SDWA's Underground Injection Control (UIC) program. All injection wells are assigned to five classes. Salt caverns for disposing of oil field waste and wells for disposing of produced water are Class II wells.

States seeking authority to administer the UIC program may obtain primacy in two ways. Under Section 1422 of the SDWA, states must demonstrate that their regulations are at least as stringent as those adopted by the EPA. To provide greater flexibility for states administering Class II 
programs, Congress added Section 1425 to the SDWA, which requires states seeking delegation to have an underground injection program that meets the requirements of Section 1421 (b)(1)(A)-(D) and would be effective enough to prevent any underground injection that would endanger drinking water sources.

\subsection{CWA REGULATES DISCHARGES OF OIL FIELD WASTES INTO SURFACE WATER}

Under the CWA, the EPA must establish effluent limitations guidelines (ELGs) for most major industrial categories. The ELGs prohibit the majority of oil and gas exploration and production wells from discharging oil field wastes. However, offshore wells and wells in Cook Inlet, Alaska, are allowed to discharge most types of oil field wastes, subject to the requirements of National Pollutant Discharge Elimination System (NPDES) permits. The ELGs also do not establish any requirements for stripper oil wells (wells producing less than $10 \mathrm{bbl}$ per day of oil). Wells in the agricultural and wildlife use subcategory may discharge produced water to surface water under the requirements of an NPDES permit. Some western U.S. operators can dispose of their relatively fresh produced waters to irrigation ditches under this subcategory.

Surface water discharge is not an available option for onshore wells, other than those in the stripper well and agricultural and wildlife use subcategories, and onshore wells make up the largest segment of U.S. oil and gas wells. Onshore wells must dispose of oil field wastes on-site or off-site at land-based or underground facilities. Some onshore wells may discharge produced water or other aqueous wastes to sanitary sewer systems.

\subsection{STATES REGULATE WASTE MANAGEMENT}

The DOE/IOGCC (1993) study provides a thorough overview of the waste management requirements of 17 oil- and gas-producing states. Some regulatory changes have occurred since 1993, but the majority of the information in that report remains accurate. As of 1992 (the year in which data for a 1993 report would have been collected), all of the 17 states surveyed allowed most types of oil field wastes to be disposed of on-site by means of a variety of methods. Not every state allows all disposal methods (e.g., Kansas does not allow land spreading of drilling wastes; Louisiana does not allow pits in coastal areas; and Michigan and North Dakota prohibit annular injection), but each state allows several disposal options. Appendix B of DOE/IOGCC (1993) provides a detailed state-by-state discussion of oil and gas waste management requirements and approved disposal methods.

Most states follow the EPA's determination to exempt oil field wastes from hazardous waste requirements. California is an exception to this policy; it does not offer a blanket exemption from 
hazardous waste requirements. California requires testing of all wastes; wastes that test as hazardous, regardless of their source, must be handled as hazardous wastes.

The IOGCC has also developed waste management guidelines for state oil and gas regulatory programs that recognize and support on-site disposal of nonhazardous oil and gas wastes (IOGCC 1994). Individual states are not bound by the IOGCC guidelines, but the guidelines serve as a good indication of what types of practices states do allow. IOGCC (1994) contains general and administrative criteria and technical criteria for on-site pits, land spreading, burial and landfilling, road spreading, tanks, and off-site commercial and centralized disposal facilities. 


\section{AVAILABILITY AND COST OF OFF-SITE COMMERCIAL DISPOSAL FACILITIES}

Section 2 documented that much of the associated wastes and some drilling wastes are sent to off-site commercial facilities for disposal. However, the references cited in that section do not provide information on the types of disposal methods employed by the commercial disposal facilities or the price an operator must pay for disposal at those facilities. This section describes the results of a survey conducted by Argonne National Laboratory from July 1996 to March 1997 that collected such information. The information contained here is derived from either written materials provided by commercial disposal companies or telephone interviews between the author and the disposal companies.

\subsection{APPROACH AND FOCUS OF THE SURVEY}

The initial intent of the survey was to compare the disposal costs at the four salt cavern disposal facilities currently in operation in Texas with the costs of other, more established disposal methods. The findings were then to be used to assess whether cavern disposal could compete on a cost basis with the other disposal methods. Consequently, the survey was initially limited to those states that both produced significant levels of oil and gas and contained salt formations that were thick enough and near enough to the surface to be economically used for cavern disposal.

The resulting data were sparse enough that the survey was expanded to include commercial disposal activities in all other major oil- and gas-producing states. Thus the survey developed a second focus; it was the basis for assembling a national database on commercial waste disposal costs.

Commercial off-site produced water disposal wells are found in many of the oil- and gasproducing states. The survey was not initially intended to consider commercial off-site disposal facilities for produced water. However, some commercial disposal companies operate separate facilities - some for disposal of solid or semisolid wastes like drilling wastes or associated wastes, and others for disposal of produced water. Those companies provided information on disposal costs for both categories of waste. Therefore, the survey was expanded to include some information on a limited number of commercial companies that dispose of produced water. The data presented here are believed to be a reasonable representation of commercial disposal costs for the states in which those disposal companies are located. Those costs may or may not be transferable to other oil- and gas-producing states.

Data were collected in two steps. First, representatives of state oil and gas regulatory agencies were contacted to determine if a list of permitted commercial disposal companies was 
available. Then, if such a list existed, each company on the list was contacted by phone. If a state agency had no list of commercial disposal companies, state officials were asked to describe how operators in that state disposed of their nonhazardous oil field waste. Commercial disposal companies were asked what type of wastes they accepted, what type of disposal method they employed, and how much they charged for disposal, exclusive of transportation costs. The majority of companies surveyed willingly provided information. A few companies elected not to participate, primarily out of concern that the cost information might be used to their competitive disadvantage. These companies are not discussed in the following sections or listed in the tables on disposal companies. The resulting information on the availability and cost of off-site commercial disposal companies is provided by state in the following sections.

\subsection{STATES WITH INDUSTRY-SPECIFIC OFF-SITE COMMERCIAL DISPOSAL}

In several states, there are many off-site commercial disposal companies that are dedicated to accepting only oil field wastes. In these states, this type of facility handles most of the oil field waste that is sent off-site. In other states, a combination of oil-industry-specific disposal facilities and other more general industrial waste disposal facilities receive oil field waste that is sent off-site. This section describes the availability of off-site disposal and the disposal methods used at these commercial sites. Table 8 lists companies that dispose of solid and oily wastes (which correspond to associated wastes and oil-based drilling wastes). Table 9 lists companies that dispose of produced water, rain water, and other dirty-water-type wastes. Table 10 lists companies that dispose of waterbased drilling wastes. As noted in the previous section, only a few off-site commercial companies for disposal of produced water are included in the discussion.

The inclusion of disposal companies in Tables 8-10 does not constitute an endorsement of those companies or provide any indication of their performance capabilities. The companies are included solely to provide an indication of the types of commercial disposal options available to operators in the 1996-1997 time frame.

\subsubsection{Arkansas}

Hampton Bussey of the Arkansas Oil and Gas Commission indicated that if sufficient surface casing has been set to satisfy state and EPA requirements, drilling fluids are injected into wells on-site. Drilling fluids that are not injected into the wellbore are either recycled or buried 
TABLE 8 Disposal Costs for Solid and Oily Nonhazardous Oil Field Wastes

\begin{tabular}{|c|c|c|c|c|}
\hline State & Company & Type & $\operatorname{Cost}^{\mathrm{a}}$ & Comments \\
\hline AR & B\&C Oilfield Construction & Recycle & $\$ 0-\$ 40 /$ hour & $\begin{array}{l}\text { Tank bottoms only; no charge for first } 4 \text { hours, } \$ 40 / \text { hour after that; } \\
\text { they clean tanks, accumulate tank bottoms, and sell to a refinery }\end{array}$ \\
\hline AR & Arkansas Service Company & Recycle & \$45/hour & $\begin{array}{l}\text { Tank bottoms only; they clean tanks, accumulate tank bottoms, and } \\
\text { sell to a refinery }\end{array}$ \\
\hline $\mathrm{CA}$ & VenVirotek & Chem. treat/reuse & $\$ 15-\$ 25 /$ ton & After treatment, used for landfill cover \\
\hline CA & Terrain Technology & Chem. treat/reuse & $\$ 12-\$ 25 /$ ton & $\begin{array}{l}\text { Make dust control product; drilling muds are evaporated and reused, } \\
\$ 3-\$ 6 / b b l\end{array}$ \\
\hline CA & Morton Recycling & Bio. treat/reuse & $\$ 12.50-\$ 28.50 / \mathrm{yd}^{3}$ & After treatment, used for fill dirt \\
\hline $\mathrm{CA}$ & Crosby and Overton & Thermal treat/reuse & $\$ 10.50 / \mathrm{bbl}$ & Cost is for bulk liquids; solids are $\$ 50 /$ drum $(\$ 38 / \mathrm{bbl})$; used as soil \\
\hline CA & Demeno Kerdoon & Treat/reuse & $\$ 0-\$ 4.20 / \mathrm{bbl}$ & Cost is based on \% of water; only takes liquids and sludges; no solids \\
\hline CA & Liquid Waste Mgmt.-McKittrick & Treat/reuse & $\$ 45 /$ ton & Used for road base material \\
\hline CA & Evergreen Oil & Reuse & $\$ 52-\$ 77 / \mathrm{bbl}$ & $\begin{array}{l}\text { Tank bottoms only; collects other wastes but sends to a third party for } \\
\text { disposal }\end{array}$ \\
\hline CA & Laidlaw-Lokern & Landfill & $\$ 30-\$ 60 / 10 n$ & $\$ 4.20-\$ 18.90 / \mathrm{bbl}$ for liquids \\
\hline $\mathrm{CA}$ & Laidlaw-Imperial Valley & Landfill & $\$ 45 /$ ton & Liquids can be solidified and landfilled at $\$ 150 /$ ton \\
\hline $\mathrm{CA}$ & Simi Valley Landfill & Landfill & $\$ 30-\$ 40 /$ ton & \\
\hline $\mathrm{CA}$ & Rollins OPC & Landfill - haz.waste & $\$ 150 /$ ton & Cost is for contam. soil; no treatment at this site, sent off-site \\
\hline CA & Chem. Waste Mgmt.-Kettleman & Landfill - haz.waste & $\$ 125 /$ ton & \\
\hline $\mathrm{CA}$ & Filler Recycling & Landspread & $\$ 95 /$ ton & $\begin{array}{l}\text { \$38/bbl; no treatment at this site; it packages in bulk and sends } \\
\text { off-site }\end{array}$ \\
\hline $\mathrm{CO}$ & Waste Management-Aurora & Landfill & $\$ 12-\$ 20 / y d 3$ & $\begin{array}{l}\text { Some waste is biologically treated to speed up breakdown of } \\
\text { hydrocarbons }\end{array}$ \\
\hline $\mathrm{CO}$ & Conservation Services & Landfill & $\$ 12-\$ 22 / \mathrm{yd}^{3}$ & Some waste is landspread at $\$ 10.50-\$ 18.90 / \mathrm{bbl}$ \\
\hline $\mathrm{co}$ & Laidlaw-Erie & Landfiill & $\$ 10.80 / \mathrm{yd}^{3}$ & \\
\hline $\mathrm{CO}$ & Strategic Environ. Solutions & Thermal trealment & $\$ 30-\$ 100 /$ ton & $\begin{array}{l}\text { Operated as stationary or mobile units; may incorporate wastes into } \\
\text { asphalt }\end{array}$ \\
\hline
\end{tabular}


TABLE 8 (Cont.)

\begin{tabular}{|c|c|c|c|c|}
\hline Stace & Company & Type & $\operatorname{Cost}^{\mathrm{a}}$ & Comments \\
\hline FL & Rinker-Miami & Incinerator & $\$ 26-\$ 30 /$ ton & Costs are for tank bottoms or contaminated soils \\
\hline LA & Campbell Wells-Mermentau & Land spread & $\$ 9.50 / \mathrm{bbl}$ & \\
\hline LA & Campbell Wells-Elm Grove & Land spread & $\$ 9.50 / \mathrm{bbl}$ & \\
\hline LA & Campbell Wells-Bourg & Land spread & $\$ 9.50 / \mathrm{bbl}$ & \\
\hline LA & Campbell Wells-Bateman Island & Land spread & $\$ 9.50 / \mathrm{bbl}$ & \\
\hline LA & Newpark-Morgan City & Treat/injection & $\$ 8.50-\$ 11 / \mathrm{bbl}$ & $\begin{array}{l}\text { Depends on oil and gas (o\&g) content; treated solids sold for landfill } \\
\text { cover material }\end{array}$ \\
\hline LA & Newpark-Fourchon & Treat/injection & $\$ 8.50-\$ 11 / \mathrm{bbl}$ & $\begin{array}{l}\text { Depends on o\&g content; treated solids sold for landfill cover } \\
\text { material }\end{array}$ \\
\hline LA & Newpark-Venice & Treat/injection & $\$ 8.50-\$ 11 / \mathrm{bbl}$ & $\begin{array}{l}\text { Depends on o\&g content; treated solids sold for landfill cover } \\
\text { material }\end{array}$ \\
\hline LA & Newpark-Intracoastal City & Treat/injection & $\$ 8.50-\$ 11 / \mathrm{bbl}$ & $\begin{array}{l}\text { Depends on o\&g content; treated solids sold for landfill cover } \\
\text { material }\end{array}$ \\
\hline LA & Newpark-Cameron & Treatinjection & $\$ 8.50-\$ 11 / \mathrm{bbl}$ & $\begin{array}{l}\text { Depends on o\&g content; treated solids sold for landfill cover } \\
\text { material }\end{array}$ \\
\hline MS & BFI-Gulf Pines & Landfill & $\$ 20-\$ 25 /$ ton & \\
\hline MS & BFI-Big River & Landfill & $\$ 19-\$ 25 / y d^{3}$ & \\
\hline MS & BFI-Little Dixie & Landfill & $\$ 20-\$ 25 /$ ton & $\$ 23-\$ 36 / \mathrm{bbl}$ for liquids \\
\hline MS & BFl-Three Rivers & Landfill & $\$ 20 /$ ton & \\
\hline MS & Transamerican Central & Landfill & $\$ 18.50-\$ 24 /$ ton & \\
\hline MS & WMI-Plantation Oaks & Landfill & $\$ 35 /$ ton & \\
\hline MS & WMI-Prairie Blulf & Landfill & $\$ 35 /$ ion & \\
\hline MS & WMI-Pecan Grove & Landfill & $\$ 35 /$ ton & \\
\hline MS & WMI-Pine Ridge & Landfill & $\$ 35 /$ ton & \\
\hline MS & Chambers-Clearview & Landfill & $\$ 26.50 /$ ion & $\$ 18.90 / \mathrm{bbl}$ for liquids \\
\hline NM & $\mathrm{C} \& \mathrm{C}$ & Land spread & $\$ 24 / y d 3$ & Contaminated soils only \\
\hline NM & Goo-Yea & Land spread & $\$ 20 /$ ton & Contaminated solid only \\
\hline
\end{tabular}


TABLE 8 (Cont.)

\begin{tabular}{|c|c|c|c|c|}
\hline State & Company & Type & $\operatorname{Cost}^{\mathrm{a}}$ & Comments \\
\hline NM & Gandy-Marley & Land spread & $\$ 14 / y d^{3}$ & Reclamation plant for tank bottoms, $\$ 2.50-\$ 5 / \mathrm{bbl}$ \\
\hline NM & Envirotech & Land spread & $\$ 18 / y d^{3}$ & \\
\hline NM & TNT Construction & Land spread & $\$ 20 / y d^{3}$ & \\
\hline NM & Tierra & Land spread & $\$ 16-\$ 18 / y^{3}{ }^{3}$ & \\
\hline NM & Sundance & Evap.\& landfill & $\$ 2.75 / \mathrm{bbl}$ & \\
\hline NM & CRI & Evap. \& landfill & $\$ 2.50 / \mathrm{bbl}$ & $\$ 14 / \mathrm{yd}^{3}$ for solids \\
\hline NV & Nevada Hydrocarbon & Thermal treatreuse & $\$ 40-\$ 50 /$ ton & $\begin{array}{l}\text { Contaminated soils only; after treatment, soils are used for } \\
\text { construction }\end{array}$ \\
\hline NV & Las Vegas Paving & Incinerator & $\$ 20-\$ 22 / 10 n$ & Contaminated soils only \\
\hline NV & Environ. Technol. of Nevada & Landfill & $\$ 31 /$ ton or $\$ 31 / 1 / d^{3}$ & Also must pay a $\$ 650$ profile fee \\
\hline $\mathrm{OH}$ & Athens Hocking & Landfill & $\$ 17-\$ 26 /$ ton & \\
\hline $\mathrm{OH}$ & Mahoning Landfill & Landfill & $\$ 22.5-\$ 24 /$ ton & \\
\hline $\mathrm{OH}$ & Suburban South Landfill & Landfill & $\$ 22-\$ 29 / 10 n$ & \\
\hline $\mathrm{OH}$ & Countywide Recycling & Landfill & $\$ 23-\$ 24 /$ ton & \\
\hline $\mathrm{OH}$ & Mt. Eaton East & Landfill & $\$ 22.50 /$ ton & \\
\hline TX & Permian Brine Sales-Andrews & Cavern & $\$ 1.95-\$ 2.85 / \mathrm{bbl}$ & $\begin{array}{l}\text { Depends on solids \& o\&g content; discounts of } \$ 1-\$ 1.5 / \mathrm{bbl} \text { for high } \\
\text { oil content }\end{array}$ \\
\hline $\mathrm{TX}$ & Permian Brine Sales-Big Springs & Cavern & $\$ 1.95-\$ 2.85 / \mathrm{bbl}$ & $\begin{array}{l}\text { Depends on solids \& o\&g content; discounts of } \$ 1-\$ 1.5 / \mathrm{hbl} \text { for high } \\
\text { oil content }\end{array}$ \\
\hline TX & Taylor Service Co. & Cavern & $\$ 6 / \mathrm{bbl}$ & $\$ 50 / y d^{3}$ for contam. soils \\
\hline TX & Voskamp Exploration & Cavern & $\$ 2.75 / \mathrm{bbl}$ & \\
\hline TX & Newpark-Port Arthur & Treal/injection & $\$ 8.50-\$ 11 / \mathrm{bbl}$ & $\begin{array}{l}\text { Depends on o\&g content; treated solids sold for landfill cover } \\
\text { material }\end{array}$ \\
\hline$T X$ & Newpark-Ingleside & Treat/injection & $\$ 8.50-\$ 11 / \mathrm{bbl}$ & $\begin{array}{l}\text { Depends on o\&g content; Ireated solids sold for landfill cover } \\
\text { material }\end{array}$ \\
\hline$T X$ & PSL, Inc. & Land spread & $\$ 20 / y d^{3}$ & \\
\hline TX & Waste Facilities, Inc. & Land spread & $\$ 9-\$ 16 / \mathrm{bbl}$ & $\begin{array}{l}\text { For oil-based muds and tank bottoms; } \$ 25 / \mathrm{yd}^{3} \text { for contam. soil or oil- } \\
\text { based muds }\end{array}$ \\
\hline
\end{tabular}


TABLE 8 (Cont.)

\begin{tabular}{|c|c|c|c|c|}
\hline State & Company & Type & $\operatorname{Cost}^{a}$ & Comments \\
\hline TX & Campbell Well-Zapata & Land spread & $\$ 6.67-\$ 8.25 / \mathrm{bbl}$ & \\
\hline TX & RCM Oil & Land spread & $\$ 22.50 / \mathrm{yd}^{3}$ & Contaminated soils only \\
\hline$T X$ & Soil Recovery Systems & Land spread & $\$ 57 / b b l$ & $\$ 30-\$ 40 / \mathrm{yd}^{3}$ \\
\hline $\mathrm{TX}$ & Basic Remediation & Land spread & $\$ 18 / \mathrm{yd}^{3}$ & \\
\hline $\mathrm{TX}$ & J. Moss & Land spread/landfill & $\$ 5.50-\$ 7 / \mathrm{bbl}$ & Solids - $\$ 25 / y d^{3}$ \\
\hline $\mathrm{TX}$ & Westex Notrees & Landfill & $\$ 3.25 / \mathrm{bbl}$ & $\$ 15.50 / \mathrm{yd}^{3}$ \\
\hline $\mathrm{TX}$ & Westex Sacroc & Landfill & $\$ 3.25 / \mathrm{bbl}$ & $\$ 15.50 / y^{3}$ \\
\hline TX & Williams Oil Field Disposal & Pits/landfill & $\$ 2.25 / \mathrm{bbl}$ & Dry solids $-\$ 6.50 / \mathrm{yd}^{3}$ \\
\hline $\mathrm{TX}$ & Eco Mud Disposal & Chem. treat/pit & $\$ 9-\$ 12 / \mathrm{bbl}$ & $\$ 30 / \mathrm{yd}^{3}$; chemical stabilization of waste, then fill in caliche pit \\
\hline UT & Lapoint Recycle and Storage & Pit & $\$ 15 / y d^{3}$ & Cost is for contaminated soil; tank bottoms at $\$ 0.55 / \mathrm{bbl}$ \\
\hline UT & Nick Slevenson & Pit & $\$ 7 / y d^{3}$ & Contaminated soils \\
\hline UT & Water Disposal & Biol. treat./pit & $\$ 0.50 / \mathrm{bbl}$ & Contaminated soils and tank bottoms \\
\hline WY & Waste Inc.- Evanston & Pit & $\$ 37.50 / y^{3}{ }^{3}$ & Drilling wastes \\
\hline WY & Waste Inc.-LaBarge & Pit & $\$ 37.50 / \mathrm{yd}^{3}$ & Drilling wastes \\
\hline WY & Sierra Consiruction & Pit & $\$ 6 / \mathrm{bbl}$ & \\
\hline WY & Jim's Water Service-Blakes Pit & Pit & $\$ 10.50 / \mathrm{bbl}$ & \\
\hline WY & Jim's Water Service-Cannon Land & Pit & $\$ 10.50 / b b l$ & \\
\hline WY & Jim's Water Service-McBeth Pits & Pit & $\$ 10.50 / \mathrm{bbl}$ & \\
\hline WY & Jim's Water Service-Werner Ranch & Pit & $\$ 10.50 / b b l$ & \\
\hline WY & Oilfield Disposal Service & Recycle & $\$ 6 / \mathrm{bbl}$ & Tank bottoms \\
\hline WY & Great Plains Environmental & $\begin{array}{l}\text { Treat/injection or } \\
\text { NPDES }\end{array}$ & $\$ 2-\$ 5 / b b l$ & This is a general industrial wastewater treatment facility \\
\hline WY & Sweetwater Co. Solid Waste & Landspread & $\$ 50-\$ 55 / t o n$ & Contuminated soils and drilling wastes \\
\hline
\end{tabular}

a Costs were provided by disposal companies between June 1996 and March 1997 and may not reflect current costs. 
TABLE 9 Disposal Costs for Produced Water, Rain Water, and Other Water-Type Wastes

\begin{tabular}{|c|c|c|c|c|}
\hline Siate & Company & Type & $\operatorname{Cost}^{\mathrm{a}}$ & Comments \\
\hline CA & Valley Waste Disposal & Evap./injection & $\$ 0.01-\$ 0.09 / \mathrm{bbl}$ & Produced water; injection cost is $\$ 0.06 / \mathrm{bbl}$; this company is nonprofit \\
\hline KY & Magnum Drilling & Injection & $\$ 1 / \mathrm{bbl}$ & \\
\hline LA & L\&S Service & Injection & $\$ 0.40 / \mathrm{bbl}$ & Produced water \\
\hline LA & Pool Company & Injection & $\$ 0.20 / \mathrm{bbl}$ & Produced water \\
\hline LA & J\&R Systems-Lafayette & Injection & $\$ 0.35 / \mathrm{bbl}$ & Cost is for produced water; $\$ 0.45-\$ 0.95$ for rainwater \\
\hline LA & J\&R Systems-Vermillion & Injection & $\$ 0.40 / \mathrm{bbl}$ & Produced water and rainwater \\
\hline LA & Venvirotek & Injection & $\$ 0.50-\$ 0.75 / \mathrm{bbl}$ & Produced water \\
\hline LA & SWD Inc. & Injection & $\$ 0.50 / \mathrm{bbl}$ & Produced water \\
\hline LA & Saline Injection Systems & Injection & $\$ 0.31 / \mathrm{bbl}$ & Produced water \\
\hline LA & Oil Field Brine Disposal & Injection & $\$ 0.36-\$ 0.42 / \mathrm{bbl}$ & Produced water \\
\hline LA & FAS Services & Injection & $\$ 0.35 / \mathrm{bbl}$ & Produced water and other water-type wastes \\
\hline LA & Habetz Oilfield Saltwater Service & Injection & $\$ 0.29 / \mathrm{bbl}$ & Produced water and rainwater \\
\hline LA & Hallar Enterprises & Injection & $\$ 0.75 / \mathrm{bbl}$ & Produced water \\
\hline LA & Houma Salt Water Disposal & Injection & $\$ 0.50-\$ 0.75 / \mathrm{bbl}$ & For prod. water and other water-lype wastes; dirty water up to $\$ 3 / \mathrm{bbl}$ \\
\hline LA & Louisiana Tank & Injection & $\$ 0.60 / \mathrm{bbl}$ & Produced water \\
\hline LA & Teulsch & Injection & $\$ 0.50 / \mathrm{bbl}$ & Cost is for produced water; $\$ 0.75$ for other water-lype wastes \\
\hline LA & Campbell Wells-Mermentau & Injection & $\$ 0.40 / \mathrm{bbl}$ & Cost is for produced water; dirty water and rainwater $=\$ 3-\$ 6.50 / \mathrm{bbl}$ \\
\hline LA & Campbell Wells-Elm Grove & Injection & $\$ 0.40 / \mathrm{bbl}$ & Cost is for produced water; dirty water and rainwater $=\$ 3-\$ 6.50 / \mathrm{bbl}$ \\
\hline LA & Campbell Wells-Bourg & Injection & $\$ 0.50 / \mathrm{bbl}$ & Cost is for produced water; dirty water and rainwater $=\$ 3-\$ 6.50 / \mathrm{bbl}$ \\
\hline LA & Campbell Wells-Bateman Island & Injection & & Do not take produced water; dirty water and rainwater $=\$ 3 \$-9.50 / \mathrm{bbl}$ \\
\hline LA & Newpark-Morgan City & Injection & $\$ 4.50 / \mathrm{bbl}$ & Produced water, dirty water, and rainwater \\
\hline LA & Newpark-Fourchon & Injection & $\$ 4.50 / \mathrm{bbl}$ & Produced water, dirty water, and rainwater \\
\hline LA & Newpark-Venice & Injection & $\$ 4.50 / \mathrm{bbl}$ & Produced water, dirly water, and rainwater \\
\hline LA & Newpark-Intracoastal City & Injection & $\$ 4.50 / \mathrm{bbl}$ & Produced water, dirty water, and rainwater \\
\hline LA & Newpark-Cameron & Injection & $\$ 4.50 / \mathrm{bbl}$ & Produced water, dirty water, and rainwater \\
\hline
\end{tabular}


TABLE 9 (Cont.)

\begin{tabular}{|c|c|c|c|c|}
\hline State & Company & Type & $\operatorname{Cost}^{a}$ & Comments \\
\hline NM & CRI & Evaporation & $\$ 0.25 / \mathrm{bbl}$ & Produced water \\
\hline NM & Sundance & Evaporation & $\$ 0.25 / \mathrm{bbl}$ & Produced water \\
\hline NM & TNT Consiruction & Evaporation & $\$ 0.81 / \mathrm{bbl}$ & Produced water \\
\hline NM & Loco Hills & Evaporation & $\$ 0.35 / \mathrm{bbl}$ & Produced water \\
\hline NM & Sunco & Evap./injection & $\$ 0.69 / \mathrm{bbl}$ & Produced water \\
\hline NM & Basin Disposal & Injection & $\$ 0.69 / \mathrm{bbl}$ & Produced water \\
\hline OK & Eola Muds & Injection & $\$ 0.30 / \mathrm{bbl}$ & Produced water \\
\hline PA & Franklin Brine Treatment & Treat/NPDES & $\$ 1-\$ 1.50 / \mathrm{bbl}$ & Produced water and other water-type wastes \\
\hline PA & Hart Chemical & Treat/NPDES & $\$ 1.80-\$ 2.10 / \mathrm{bbl}$ & $\$ 2.10 / \mathrm{bbl}$ for produced water; $\$ 1.80 / \mathrm{bbl}$ for nonsalty water \\
\hline PA & Waste Treatment & Treat/NPDES & $\$ 1.50 / \mathrm{bbl}$ & Produced water and other water-type wastes \\
\hline PA & Allegheny Liquid Systems & Treat/POTW & $\$ 1.25 . \$ 1.80 / \mathrm{bbl}$ & Produced water and other waler-type wastes \\
\hline PA & Keystone Vacuum Services & $\begin{array}{l}\text { POTW/road } \\
\text { spread }\end{array}$ & $\$ 1.30-\$ 4.20 / \mathrm{bbl}$ & $\begin{array}{l}\text { Produced water is roadspread in summer; other water-type wastes go to } \\
\text { POTW }\end{array}$ \\
\hline PA & Moshannon Valley Treatment Plant & POTW & $\$ 0.65 / b b l$ & Other water-type wastes \\
\hline PA & Bellefonte Treatment Plant & POTW & $\$ 1.50 / \mathrm{bbl}$ & Other water-type wastes \\
\hline TX & Williams Oil Field Disposal & Injection & $\$ 0.30 / \mathrm{bbl}$ & Produced water \\
\hline $\mathrm{TX}$ & Permian Brine Sales-Big Springs & Injection & $\$ 0.32-\$ 0.50 / \mathrm{bbl}$ & Produced water \\
\hline $\mathrm{TX}$ & Taylor Service Company & Injection & $\$ 0.35 / b b l$ & Produced water \\
\hline TX & Lundy Vacuum Services-Armour & Injection & $\$ 0.30 / \mathrm{bbl}$ & Produced water \\
\hline $\mathrm{TX}$ & Lundy Vacuum Services-Wittig & Injection & $\$ 0.30 / \mathrm{bbl}$ & Produced water \\
\hline $\mathrm{TX}$ & Mo-Vac Service & Injection & $\$ 0.35 / \mathrm{bbl}$ & Produced water \\
\hline $\mathrm{TX}$ & Basic Remediation & Injection & $\$ 0.23-\$ 0.35 / \mathrm{bbl}$ & Produced water \\
\hline TX & Newpark-Port Arthur & Injection & $\$ 4.50 / \mathrm{bbl}$ & Produced water, dirty water, and rainwater \\
\hline $\mathrm{TX}$ & Newpark-Ingleside & Injection & $\$ 4.50 / \mathrm{bbl}$ & Produced water, dirty water, and rainwater \\
\hline
\end{tabular}


TABLE 9 (Cont.)

\begin{tabular}{|c|c|c|c|c|}
\hline State & Company & Type & $\operatorname{Cost}^{\mathfrak{a}}$ & Comments \\
\hline UT & Lapoint Recycle and Storage & Evaporation & $\$ 0.55 / \mathrm{bbl}$ & Produced water \\
\hline UT & Ace Disposal & Evaporation & $\$ 0.75 / \mathrm{bbl}$ & Produced water \\
\hline UT & Hansen Disposal & Evaporation & $\$ 0.50 / \mathrm{bbl}$ & Produced water \\
\hline UT & Water Disposal & Evaporation & $\$ 0.50 / \mathrm{bbl}$ & Produced water \\
\hline UT & Montezuma Well Service & Evaporation & $\$ 0.65-\$ 0.75 / \mathrm{bbl}$ & Produced water; cosis are based on truck loads \\
\hline WY & D\&B Disposal & Evaporation & $\$ 1.50 / / \mathrm{bbl}$ & condensates \\
\hline WY & Waste Inc.- Evanston & Evaporation & $\$ 1.75-\$ 2.50 / \mathrm{bbl}$ & $\$ 1.75 / \mathrm{bbl}$ for produced water; $\$ 2.50$ for other water-type wastes \\
\hline WY & Waste Inc.-LaBarge & Evaporation & $\$ 1.10-\$ 2.50 / \mathrm{bbl}$ & $\$ 1.10 / \mathrm{bbl}$ for produced water; $\$ 2.50$ for other water-lype wastes \\
\hline WY & Sierra Construction & Evaporation & $\$ 0.60 / \mathrm{bbl}$ & Produced water \\
\hline WY & Jim's Water Service-Blakes Pit & Evaporation & $\$ 1 /$ bbl & Produced water \\
\hline WY & Jim's Water Service-Cannon Land & Evaporation & $\$ 1 / \mathrm{bbl}$ & Produced water \\
\hline WY & Jim's Water Service-McBeth Pits & Evaporation & $\$ 1 / \mathrm{bbl}$ & Produced water \\
\hline WY & Jim's Water Service-Werner Ranch & Evaporation & $\$ 1 / b b l$ & Produced water \\
\hline WY & Oilfield Disposal Service & Evaporation & $\$ 0.75-\$ 1.25 / \mathrm{bbl}$ & Produced water \\
\hline WY & Mexican Flats Water Disposal & Evaporation & $\$ 1.95 / \mathrm{bbl}$ & Produced water \\
\hline WY & Great Plains Environmental & $\begin{array}{l}\text { Treat/injection } \\
\text { or NPDES }\end{array}$ & $\$ 0.96 / \mathrm{bbl}$ & Produced water \\
\hline WY & Wyoming Waste Water Disposal & Injection & $\$ 1-\$ 2.50 / \mathrm{bbl}$ & Produced water \\
\hline WY & Prima Exploration & Injection & $\$ 0.60 / \mathrm{bbl}$ & Produced water \\
\hline WY & Corlez Energy & Injection & $\$ 0.75-\$ 8 / b b l$ & Produced water and other water-type wastes \\
\hline
\end{tabular}

a Costs were provided by disposal companies from June 1996 to March 1997 and may not reflect current costs. 
TABLE 10 Disposal Costs for Water-Based Drilling Wastes

\begin{tabular}{|c|c|c|c|c|}
\hline State & Company & Type & Cost & Comments \\
\hline CA & VenVirotek & Chem.treat/reuse & $\$ 15-\$ 25 /$ ton & After treatment, used for landfill cover \\
\hline LA & Campbell Wells-Mermentau & Land spread & $\$ 7.50-\$ 9.50 / \mathrm{bbl}$ & \\
\hline LA & Campbell Wells-Elm Grove & Land spread & $\$ 7.50-\$ 9.50 / \mathrm{bbl}$ & \\
\hline LA & Campbell Wells-Bourg & Land spread & $\$ 7.50-\$ 9.50 / \mathrm{bbl}$ & \\
\hline LA & Campbell Wells-Bateman Island & Land spread & $\$ 7.50-\$ 9.50 / \mathrm{bbl}$ & \\
\hline LA & Newpark-Morgan City & Trealinjection & $\$ 7.50 / \mathrm{bb}$ & Treated solids sold for landfill cover material \\
\hline LA & Newpark-Fourchon & Trealinjection & $\$ 7.50 / \mathrm{bbl}$ & Treated solids sold for landfill cover material \\
\hline LA & Newpark-Venice & Treatinjection & $\$ 7.50 / \mathrm{bbl}$ & Treated solids sold for landfill cover material \\
\hline LA & Newpark-Intracoastal City & Treat/injection & $\$ 7.50 / \mathrm{bbJ}$ & Treated solids sold for landfill cover material \\
\hline LA & Newpark-Cameron & Treal/injection & $\$ 7.50 / \mathrm{bbl}$ & Treated solids sold for landfill cover material \\
\hline NM & CRI & Evaporation/landfill & $\$ 2.50 / \mathrm{bbl}$ & $\$ 14 / \mathrm{yd}^{3}$ for solids \\
\hline NM & Sundance & Evaporation/landfill & $\$ 2.75 / \mathrm{bbl}$ & \\
\hline NM & Gandy-Marley & Land spread & $\$ 14 / y d 3$ & \\
\hline NM & Envirotech & Land spread & $\$ 18 / y d 3$ & \\
\hline NM & TNT Construction & Land spread & $\$ 20 / y d 3$ & \\
\hline NM & Tierra & Land spread & $\$ 16-\$ 18 / y d^{3}$ & \\
\hline OK & Briggell & Pit & $\$ 0.90 / \mathrm{bbl}$ & \\
\hline OK & FPC Disposal & Pit & $\$ 0.35 / \mathrm{bbl}$ & \\
\hline OK & Gray & Pit & $\$ 0.75 / \mathrm{bbl}$ & Cost for solids $-\$ 5.20-\$ 6.25 / \mathrm{yd}^{3}$ \\
\hline OK & Eola Mud & Pit & $\$ 0.75 / \mathrm{bbl}$ & \\
\hline OK & Guard-Giles & Pit & $\$ 0.60-\$ 0.75 / \mathrm{bbl}$ & \\
\hline OK & Guard & Pit & $\$ 0.60-\$ 0.75 / \mathrm{bbl}$ & \\
\hline OK & Smith & Pit & $\$ 0.88 / \mathrm{bbl}$ & \\
\hline OK & O'Danicl Gravel & Pit & $\$ 0.50 / \mathrm{bbl}$ & \\
\hline OK & Safe Earth & Pit & $\$ 0.75-\$ 1.75 / \mathrm{bbl}$ & Cost for muds depends on chloride content; cuttings - $\$ 8.30-10 / \mathrm{yd}^{3}$ \\
\hline OK & Poleet Oil & Pit & $\$ 0.67-\$ 1 / \mathrm{bbl}$ & \\
\hline
\end{tabular}


TABLE 10 (Cont.)

\begin{tabular}{|c|c|c|c|c|}
\hline Slate & Company & Type & Cosi & Comments \\
\hline PA & Franklin Brine Treatment & TreaUNPDES & $\$ 2.50-\$ 3.50 / \mathrm{bbl}$ & \\
\hline PA & Allegheny Liquid Systems & Treat/POTW & $\$ 1.25-\$ 14.70 / \mathrm{bbl}$ & Surcharges for solids and oil \\
\hline PA & Hart Chemical & Treat/NPDES & $\$ 3.40-\$ 8.40 / \mathrm{bbl}$ & \\
\hline PA & Waste Treatment & TreaVNPDES & $\$ 2.50-\$ 12.60 / \mathrm{bbl}$ & \\
\hline PA & Bellefonte Treatment Plant & POTW & $\$ 1.50 / \mathrm{bbl}$ & \\
\hline PA & Moshannon Valley Treatment Plant & POTW & $\$ 0.65 / \mathrm{bbl}$ & \\
\hline $\mathrm{TX}$ & Permian Brine Sales-Andrews & Cavern & $\$ 1.95-\$ 2.85 / \mathrm{bbl}$ & $\begin{array}{l}\text { Depends on solids \& } 0 \& g \text { content; discounts of } \$ 1-\$ 1.5 / \mathrm{bbl} \text { for } \\
\text { high oil content }\end{array}$ \\
\hline TX & Permian Brine Sales-Big Springs & Cavern & $\$ 1.95-\$ 2.85 / \mathrm{bbl}$ & $\begin{array}{l}\text { Depends on solids \& } 0 \& \mathrm{~g} \text { content; discounts of } \$ 1 . \$ 1.5 / \mathrm{bbl} \text { for } \\
\text { high oil content }\end{array}$ \\
\hline$T X$ & Taylor Service Co. & Cavern & $\$ 6 / \mathrm{bbl}$ & \\
\hline TX & Voskamp Exploration & Cavern & $\$ 2.75 / \mathrm{bbl}$ & \\
\hline $\mathrm{TX}$ & Lundy Vacuum Service-Beasley & Land spread & $\$ 0.31-\$ 0.80 / \mathrm{bbl}$ & \\
\hline$T X$ & Lundy Vacuum Service-Humphreys & Land spread & $\$ 0.31-\$ 0.80 / \mathrm{bbl}$ & \\
\hline $\mathrm{TX}$ & F. W. Fontenot & Land spread & $\$ 0.38 / \mathrm{bbl}$ & \\
\hline $\mathrm{TX}$ & Waste Facilities, Inc. & Land spread & $\$ 5 / \mathrm{bbl}$ & \\
\hline TX & Karon Smith & Land spread & $\$ 1 / \mathrm{bbl}$ & $\$ 10 / y d 3$ for solids \\
\hline$T X$ & Eurl Nunneley & Land spread & $\$ 0.20 / \mathrm{bbl}$ & Cost is for muds; cuttings - $\$ 5 / \mathrm{yd}^{3}$ \\
\hline TX & Keith Overby & Land spread & $\$ 0.38 / \mathrm{bbl}$ & \\
\hline$T X$ & Goetz Services & Land spread & $\$ 0.19 / \mathrm{bbl}$ & \\
\hline $\mathrm{TX}$ & Campbell Wells-Zapata & Land spread & $\$ 1.50-\$ 7 / \mathrm{bbl}$ & Depends on oil and chlorides content \\
\hline $\mathrm{TX}$ & Mo-Vac Service & Pit & $\$ 1 / \mathrm{bbl}$ & \\
\hline $\mathrm{TX}$ & J. Moss & Pil & $\$ 2 / \mathrm{bbl}$ & Cost is for muds; cuttings $-\$ 6.50 / \mathrm{yd}^{3} ;$ soil $-15 / \mathrm{yd}^{3}$ \\
\hline TX & Newpark-Port Arthur & Treal/injection & $\$ 7.50 / \mathrm{bbl}$ & Treated solids sold for landfill cover material \\
\hline $\mathrm{TX}$ & Newpark-Ingleside & Treat/injection & $\$ 7.50 / \mathrm{bbl}$ & Treated solids sold for landfill cover material \\
\hline UT & Ace Disposal & Pit & $\$ 1.50 / \mathrm{bbl}$ & \\
\hline
\end{tabular}




\section{TABLE 10 (Cont.)}

\begin{tabular}{|c|c|c|c|c|}
\hline State & Company & Type & Cost & Comments \\
\hline WY & Waste Inc. - Evanston & Pit & $\$ 37.50 / y^{3}{ }^{3}$ & \\
\hline WY & Waste Inc.-LaBarge & Pit & $\$ 37.50 / \mathrm{yd}^{3}$ & \\
\hline WY & Sierra Construction & Pit & $\$ 1-\$ 2 / b b l$ & . \\
\hline WY & Jim's Water Service-Blakes Pit & Pit & $\$ 10.50 / \mathrm{bbl}$ & \\
\hline$W Y$ & Jim's Water Service-Cannon Land & Pit & $\$ 10.50 / \mathrm{bbl}$ & \\
\hline WY & Jim's Water Service-McBeth Pits & Pit & $\$ 10.50 / \mathrm{bbl}$ & \\
\hline WY & Jim's Water Service-Werner Ranch & Pit & $\$ 10.50 / \mathrm{bbl}$ & \\
\hline WY & Great Plains Environmental & Treatinjection or NPDES & $\$ 2-\$ 5 / \mathrm{bbl}$ & This is a general industrial wastewater treatment facility \\
\hline WY & Sweetwater Co. Solid Waste & Landspread & $\$ 50-\$ 55 /$ ton & \\
\hline
\end{tabular}

a Costs were provided by disposal companies from June 1996 to March 1997 and may not reflect current costs. 
on-site. He also stated that tank bottoms are handled by commercial reclaimers. ${ }^{1}$ Dennis Endel of the Oil and Gas Commission provided a list of several reclaimers. All were contacted, but only two provided information. These two are listed in Table 8 . The reclaimers come to the oil field site and clean out tank bottoms. They then take the tank bottoms back to their facility, where the bottoms accumulate until their volume is sufficient to be sold to a refinery.

\subsubsection{California}

William Guerard and Hal Bopp of the California Department of Conservation indicated that although there are commercial oil field waste disposal companies in California, no formal comprehensive list of them is available. They provided the names of several companies, who, in turn, provided the names of other companies. M.G. Mefferd of the Conservation Committee of California Oil and Gas Producers provided an additional list of disposal companies. All facilities identified through this process were contacted. Facilities that provided information are listed in Tables 8-10. Table 8 lists five hazardous and nonhazardous waste landfills that accept oil field waste and six facilities that chemically, biologically, or thermally treat solid and oily wastes and convert them into usable by-products. One of these facilities also treats water-based drilling wastes for reuse, as shown in Table 10. Table 8 also identifies a facility that receives oil field wastes, assembles them in bulk, and transports them to an off-site land spreading operation. Table 9 identifies one facility that disposes of produced water through injection and evaporation and fresh water through irrigation.

\subsubsection{Louisiana}

Carroll Wascom of the Department of Natural Resources provided a list of approved commercial disposal facilities. Every facility on the list was contacted. Those facilities that provided information are listed in Tables 8-10. Tables 8 and 10 identify four land spreading sites and five sites that treat the wastes, inject the liquids, and recycle the solids as landfill cover material. Table 9 shows 23 commercial injection wells operated by 15 companies.

1 Although the practice of reclaiming tank bottoms may occur throughout a large portion of the United States, the data collected for this study are not adequate to draw nationwide conclusions. Many of the state representatives we interviewed did not provide information on reclaiming activities in their states. When reclaimers were identified, they were contacted, and if they provided information, it is included in Table 8. In EPA (1994), there is a table (Table B-1) that summarizes a study by the Interstate Oil and Gas Compact Commission and identifies reclaimers in 15 oil- and gas-producing states. 


\subsubsection{New Mexico}

Mark Ashley and Denny Faust of the New Mexico Oil Conservation Division provided a list of approved commercial disposal facilities. Every facility on the list was contacted. Facilities that provided information are listed in Tables 8-10. Table 8 identifies six land spreading operations and two facilities that use evaporation and landfills for disposing of solid and oily wastes. Table 9 shows that four facilities use evaporation, one uses injection, and another uses both evaporation and injection for disposing of produced water. Table 10 identifies four land spreading operations and two facilities that use evaporation and landfills for disposing of water-based drilling wastes.

\subsubsection{Oklahoma}

Bruce Langhus of the Oklahoma Corporation Commission provided a list of active commercial disposal pits that are authorized to accept only water-based drilling wastes. All facilities on that list were contacted. The 10 facilities that provided information are listed in Table 10. One of these facilities also operates a injection well for produced water disposal, as shown in Table 8. A lengthy list of commercial well companies for disposal of produced water was also provided. These companies were not contacted and are not shown on Table 9.

\subsubsection{Pennsylvania}

James Erb of the Pennsylvania Department of Environmental Protection indicated that most nonhazardous oil field wastes are disposed of on-site. Although operators could take wastes to landfills, he was not aware of any operators that did. Ron Gilius, also of the Department of Environmental Protection, provided a list of commercial facilities that receive oil field waste. Most of these disposal facilities dispose of only produced water and were not contacted. Several other facilities that dispose of both produced water and drilling and frac fluids were contacted. Table 9 lists one facility that treats the waste and then discharges it to a publicly owned treatment works (POTW), two facilities that are POTWs, and three facilities that treat the waste and then discharge it to surface waters through in a National Pollutant Discharge Elimination System (NPDES) permit. All of these facilities also dispose of water-based drilling wastes and are listed in Table 10.

One other company, referred to by Mr. Gilius as a service company, collects wastes and transports them to a POTW. This company also spreads produced water on roads during the summer, which is considered a beneficial use of a waste material by the Department of Environmental Protection. There are other service companies operating in Pennsylvania, but they were not identified or contacted. 


\subsubsection{Texas}

Jill Hibner of the Railroad Commission of Texas provided a list of approved commercial disposal facilities. Every facility on the list was contacted. Facilities that provided information are listed in Tables 8-10. Table 8 identifies 17 facilities that dispose of solid and oily wastes, including seven land spreading operations, four facilities that use salt caverns, four that use pits or landfills (one of which chemically stabilizes the waste first), and two that process solid wastes for reuse and inject liquid wastes.

Table 9 identifies nine facilities that employ injection for disposing of produced water, rain water, and other water-type wastes. Table 10 identifies 17 facilities for disposing of water-based drilling wastes, including nine land spreading operations, four facilities that use salt caverns, two that use pits or landfills, and two that process solid wastes for reuse and inject liquid wastes.

\subsubsection{Utah}

Gil Hunt of the Utah Department of Natural Resources provided a list of approved disposal pits. Every facility on the list was contacted. Facilities that provided information are listed in Tables 8-10. Table 8 identifies three facilities that accept contaminated soils. Two of those facilities also accept tank bottoms. Table 9 lists five facilities that dispose of produced water through evaporation in pits. Table 10 lists one facility that disposes of water-based drilling wastes.

\subsubsection{Wyoming}

Bob Lucht and Larry Robinson of the Wyoming Department of Environmental Quality provided a list of approved disposal pits. Every facility on the list was contacted. Facilities that provided information are listed in Tables 8-10. Table 8 identifies seven facilities that dispose of solid and oily wastes in pits, one that land spreads, and one that recycles tank bottoms. Table 9 identifies 10 facilities that evaporate produced water and other water-type wastes, three that employ injection, and the industrial treatment facility described above. Table 10 lists seven facilities that dispose of water-based drilling wastes in pits and one that land spreads. One additional facility, which treats the waste in an industrial treatment plant and then either injects it to a well or discharges it to surface waters through an NPDES permit, is listed in all three tables. 


\subsection{STATES WITHOUT INDUSTRY-SPECIFIC OFF-SITE COMMERCIAL DISPOSAL}

Some oil- and gas-producing states support a network of industry-specific commercial disposal facilities; these are described in the previous section. Most other oil-and gas-producing states are unable to support this type of network. In this second group of states, most nonhazardous oil field wastes are disposed of on-site. The wastes that must go off-site for disposal are sent to local sanitary landfills, industrial disposal facilities not specific to the oil and gas industry, or out of state. The information obtained through interviews with representatives of these states is described below. Since sanitary landfills represent the primary off-site disposal option for operators in many of these states, information on landfill availability and cost was gathered from several states that represent different parts of the country: California, Colorado, Mississippi, and Ohio.

\subsubsection{Alabama}

David Bolin of the Alabama Oil and Gas Board indicated that most nonhazardous oil field waste is disposed of on-site. Tank bottoms are generally sent off-site to a commercial disposal facility. He was unable to identify any disposal facilities that specifically handle oil and gas industry wastes. Tank bottoms and other wastes that are sent off-site probably go to a local landfill or hazardous waste disposal facility or to an out-of-state facility for disposal.

\subsubsection{Alaska}

Jack Hartz of the Alaska Oil and Gas Conservation Commission indicated that all nonhazardous oil field wastes in Alaska are disposed of on-site.

\subsubsection{Arizona}

Steve Rauzi of the Arizona Geological Survey, which provides staff support for the Oil and Gas Conservation Commission, reported that all oil field wastes are either disposed of on-site or sent to disposal facilities in neighboring states.

\subsubsection{Colorado}

Robin Reade of the Colorado Oil and Gas Conservation Commission indicated that much of Colorado's oil and gas waste is disposed of on-site or at off-site land farms owned and operated by the oil companies for their own wastes. Table 8 lists three sanitary landfills that accept oil field 
wastes. One landfill offers biological treatment before landfilling to speed up degradation. A second landfill also offers land spreading. A fourth company provides thermal treatment for contaminated soils but does not treat or dispose of other types of oil field wastes.

\subsubsection{Florida}

Don Hargrove, Paul Attwood, and Ed Garrett of the Florida Geological Survey indicated that drilling wastes are disposed of on-site. Contaminated soils and tank bottoms are incinerated. One commercial incinerator is identified in Table 8.

\subsubsection{Illinois}

Lawrence Bengal of the Illinois Department of Natural Resources reported that Illinois has 12 commercial produced water disposal wells. These companies were not contacted and do not appear in Table 9. Most other oil field wastes are disposed of on-site. Those wastes that are sent offsite are taken to sanitary landfills or sent out of state.

\subsubsection{Indiana}

Mike Nickolaus of the Indiana Department of Natural Resources reported that most wastes are disposed of on-site. Some wastes may be sent to "special waste" landfills.

\subsubsection{Kansas}

William Bryson of the Kansas Geological Survey and Richard Bronaugh and Joe Cronin of the Kansas Department of Health and Environment were interviewed. They suggested that most oil field wastes generated in Kansas are disposed of on-site. None of these officials were aware of any commercial waste disposal facilities in Kansas that are operated solely for handling oil field wastes, although there might be some commercial disposal wells for produced water. Wastes that cannot be disposed of on-site are probably sent to local sanitary or industrial landfills or to commercial disposal facilities in other states.

\subsubsection{Kentucky}

James Hale and Dan Juett of the Kentucky Department for Environmental Protection indicated that drilling wastes are disposed of on-site by land spreading. Produced water is disposed 
of through underground injection, enhanced evaporation, or NPDES-permitted discharge. Tank bottoms and other nonhazardous wastes are sent to landfills permitted to accept such wastes. Hale and Juett reported that two commercial injection wells dispose of produced water. One of these companies is identified in Table 9. The other company could not be contacted.

\subsubsection{Maryland}

Molly Gary of the Maryland Department of the Environment reported that cuttings are disposed of on-site but that drilling fluids are taken to an out-of-state disposal facility.

\subsubsection{Michigan}

Tom Segall and Joan Peck of the Michigan Department of Environmental Quality were interviewed. Neither official was aware of any commercial waste disposal facilities in Michigan that are operated solely to handle oil field wastes. Wastes that cannot be disposed of on-site are probably sent to local sanitary or industrial landfills or commercial disposal facilities in other states.

\subsubsection{Mississippi}

Fred Hille of the Mississippi Oil and Gas Board indicated that there are presently no commercial waste disposal companies in Mississippi that are operated solely for handling nonhazardous oil field wastes. Several facilities are licensed to handle naturally occurring radioactive material (NORM) associated with oil and gas activities. This report does not focus on NORM disposal, so those facilities were not identified. Jeff Lundy, also of the Oil and Gas Board, indicated that in early 1997, an oil field waste disposal company had expressed interest in operating a disposal facility in Mississippi. This facility is not currently licensed or operational and is therefore not included in Tables 8-10.

Wastes that cannot be disposed of on-site are sent to local sanitary or industrial landfills or to commercial disposal facilities in other states. Because Mississippi was selected as an example of a Gulf Coast state in which solid waste landfills are used for oil field waste disposal, additional data on landfills were collected. Mark Williams and James Crawford of the Mississippi Department of Environmental Quality provided a list of Mississippi's 17 active municipal solid waste landfills. Eleven of those facilities, located in oil- and gas-producing parts of the state, were contacted. One of these landfills does not accept oil field wastes. The remaining 10 landfills are listed in Table 8. 


\subsubsection{Missouri}

Evan Kifer of the Missouri Department of Natural Resources indicated that drilling wastes are disposed of on-site but that contaminated soils are sent to landfills. James Williams, also of the Department of Natural Resources, reported that some coal bed methane production wastewater has been transported out of state for disposal.

\subsubsection{Montana}

Tom Richmond of the Montana Board of Oil and Gas Conservation reported that the majority of oil field wastes are disposed of on-site. There is one special landfill in Montana that can accept oil field wastes if necessary.

\subsubsection{Nebraska}

Stan Belieu of the Nebraska Oil and Gas Commission suggested that most oil field wastes generated in Nebraska are disposed of on-site. He was unaware of any commercial waste disposal facilities in Nebraska that are operated solely for handling oil field wastes. Wastes that cannot be disposed of on-site are probably sent to local sanitary or industrial landfills or to commercial disposal facilities in other states.

\subsubsection{Nevada}

Russ Land of the Nevada Department of Conservation and Natural Resources indicated that all produced waters are disposed of through injection wells and all nonhazardous drilling and associated wastes are disposed of on-site. John Snow of the Nevada Division of Minerals reported that heavily contaminated soils and tank bottoms are sent to two thermal treatment facilities or a hazardous waste landfill, as listed in Table 8.

\subsubsection{New York}

Brad Field of the New York Department of Environmental Conservation indicated that some wastes are disposed of on-site but that many oil field wastes are sent either to sanitary landfills or to out-of-state disposal facilities. 


\subsubsection{North Dakota}

Charles Koch of the North Dakota Industrial Commission reported that most wastes are disposed of on-site but contaminated soils are taken to an approved landfill for disposal. North Dakota has numerous commercial disposal wells. These were not identified or contacted and do not appear in Table 9.

\subsubsection{Ohio}

Dennis Crist of the Ohio Department of Natural Resources indicated that there are no commercial waste disposal companies in Ohio operated solely for handling nonhazardous oil field wastes. Most oil field wastes generated in Ohio are disposed of on-site. Wastes that cannot be disposed of on-site are sent to local sanitary or industrial landfills or to commercial disposal facilities in other states. Because Ohio was selected as an example of a northern state in which solid waste landfills are used for oil field waste disposal, additional data on landfills were collected. George Kaiser of the Ohio Environmental Protection Agency provided a list of Ohio's licensed solid waste landfills. Five of those landfills, located in oil- and gas-producing parts of the state, were contacted and are listed in Table 8.

\subsubsection{South Dakota}

Mac MacGillivray of the South Dakota Department of Environment and Natural Resources reported that most oil field wastes are disposed of on-site or by neighboring operators. If wastes need to go off-site, they are sent to sanitary landfills or taken out of state.

\subsubsection{Virginia}

Bob Wilson of the Virginia Department of Mines, Minerals, and Energy indicated that drill cuttings are disposed of on-site but other solid wastes are sent off-site to approved landfills or other general waste disposal facilities. Liquid wastes are disposed of in injection wells or taken out of state to licensed facilities for disposal.

\subsubsection{West Virginia}

Jamie Sturm of the West Virginia Department of Natural Resources indicated that most nonhazardous oil field waste is disposed of on-site. Tank bottoms are generally sent off-site to a commercial disposal facility. He identified three Pennsylvania facilities that handle oil field wastes. 
Other West Virginia operators may send their wastes to local landfills. Gene Smith, also of the Department of Natural Resources, reported that West Virginia has six commercial disposal wells for produced water. These companies were not contacted and do not appear in Table 9.

\subsection{COSTS OF OFF-SITE COMMERCIAL DISPOSAL}

Tables 8-10 list the costs for the off-site commercial disposal of solid and oily wastes, produced water (including rain water and other water-type wastes), and water-based drilling wastes, respectively. These costs are discussed by waste type and disposal method in the text that follows. The costs represent only the cost for disposal and do not include other costs associated with transportation or vehicle washout. Many companies indicated they would offer discounts from their standard rates for large volumes of waste.

The costs included in Tables 8-10 are those that were provided by each disposal company to the author during June 1996 and March 1997. They are included in this report for comparative purposes at one point in time. There is no guarantee that those costs reflect the actual costs that would be charged to customers or that these companies still charge the same costs.

Costs are expressed in different units of measurement. Most costs are expressed as $\$ / \mathrm{bbl}$, but others are expressed as $\$ /$ cubic yard $\left(\$ / y^{3}\right)$ and $\$ /$ ton. The $\$ / y d^{3}$ unit is often used when the wastes are predominantly solids, and the $\$ /$ ton unit is commonly used by landfills because costs for disposal of municipal solid waste are based on $\$ /$ ton. For the sake of comparison, one can convert the latter two units into $\$ / \mathrm{bbl}$, although the result is only an approximation, at best. To convert a volume-based unit (barrels or cubic yards) to a weight-based unit (tons), the specific gravity of the waste must be considered. If one assumes that oil field waste has a specific gravity that is 1.5 times that of water, the conversion factors are $1 \mathrm{yd}^{3}=4.81 \mathrm{bbl}$ and 1 ton $=3.81 \mathrm{bbl}$. The conversions are not shown in Tables 8-10 but are provided in several places in the following sections to describe overall cost patterns.

\subsubsection{Solid and Oily Waste}

Costs for these wastes are found in Table 8. Overall, disposal costs range from $\$ 0-\$ 57 / \mathrm{bbl}$, $\$ 6.50-\$ 50 / \mathrm{yd}^{3}$ (comparable to $\$ 1.35-\$ 10.40 /$ converted bbl), and $\$ 12-\$ 150 /$ ton (comparable to $\$ 3.15-\$ 39.40 /$ converted bbl). The highest cost per bbl, $\$ 57 / \mathrm{bbl}$, appears to be a true outlier. At the facility that charges that price, it costs less to dispose of a cubic yard of waste than a barrel of waste. This apparent anomaly can be attributed to the facility's reluctance to handle individual barrels rather than handling bulk wastes. After removing that anomalous value, the range becomes $\$ 1.95-\$ 38 / \mathrm{bbl}$. Several of the facilities that charge high per-ton rates are facilities that also accept hazardous wastes for disposal. 
Land spreading operations have a significant share of the commercial disposal market. Prices are $\$ 5.50-\$ 57 / \mathrm{bbl}$ and $\$ 14-\$ 40 / \mathrm{yd}^{3}$, with most costs falling in the range of $\$ 7-\$ 9.50 / \mathrm{bbl}$ and $\$ 18-\$ 25 / y^{3}$. Two land spreading facilities quoted a per-ton rate of $\$ 20-\$ 95 /$ ton.

Landfills and pits represent another important disposal option for solid and oily wastes. Prices in Texas are $\$ 2.25-\$ 3.25 / \mathrm{bbl}$ and $\$ 6.50-\$ 25 / \mathrm{yd}^{3}$, while Wyoming prices are $\$ 6-\$ 10.50 / \mathrm{bbl}$ and $\$ 37.50 / \mathrm{yd}^{3}$. Two Utah facilities charge $\$ 7-\$ 15 / \mathrm{yd}^{3}$, and another charges $\$ 0.50 / \mathrm{bbl}$. Two New Mexico facilities evaporate the liquid fraction of the waste and then send the solids to landfills. They charge $\$ 2.50-\$ 2.75 / \mathrm{bbl}$ and $\$ 14 / \mathrm{yd}^{3}$ for solids.

The Texas, Wyoming, Utah, and New Mexico landfills and pits in Table 8 are dedicated to receiving just oil field wastes, while the landfills in the other states are general solid waste or hazardous waste landfills that typically charge by the ton. Costs for disposing of solid wastes at landfills vary somewhat, depending on the state. For example, weight-based rates in Mississippi are $\$ 18.50-\$ 35 /$ ton; those in Ohio are $\$ 17-\$ 29 /$ ton; and those in California are $\$ 30-\$ 40 /$ ton at nonhazardous landfills and $\$ 30-\$ 150 /$ ton at hazardous waste landfills. One Nevada landfill charges $\$ 31 /$ ton. Three Colorado landfills charge $\$ 10.80-\$ 22 / \mathrm{yd}^{3}$. Two Mississippi landfills will accept liquids at a much higher rate of $\$ 18.90-\$ 36 / \mathrm{bbl}$, and one Mississippi landfill charges $\$ 19-\$ 25 / \mathrm{yd}^{3}$.

Several other disposal facilities treat the wastes before disposing of or reusing them. Five Louisiana facilities and two Texas facilities treat and reuse the solid part of the waste and inject the liquid part at a cost of $\$ 8.50-\$ 11 / \mathrm{bbl}$. Another Texas facility first chemically stabilizes the waste and then landfills it at a cost of $\$ 9-\$ 12 / \mathrm{bbl}$ and $\$ 30 / \mathrm{ton}$. Five California facilities biologically or chemically treat waste and then reuse it at a cost of $\$ 12-\$ 45 / \mathrm{ton}, \$ 12.50-\$ 28.50 / \mathrm{yd}^{3}$, and $\$ 0-\$ 6 / \mathrm{bbl}$. One of these facilities charges $\$ 0-4.20 / \mathrm{bbl}$ but only accepts liquids and sludges.

Several facilities use thermal treatment or incineration followed by reuse or disposal of the residues. Costs are $\$ 10.50-\$ 38 / \mathrm{bbl}$ and $\$ 20-\$ 100 /$ ton.

One California commercial facility evaporates liquid wastes in a surface impoundment at a cost of $\$ 4.20-\$ 18.90 / \mathrm{yd}^{3}$.

Several companies identified in this survey reclaim tank bottoms. Two Arkansas reclaimers charge by the hour. One charges $\$ 45 /$ hour, and the other charges nothing for the first four hours and $\$ 40 /$ hour for each additional hour. One New Mexico company and one Wyoming company reclaim tank bottoms at costs from $\$ 2.50-\$ 6 / \mathrm{bbl}$.

A Wyoming company operates a sophisticated industrial wastewater treatment plant that either injects the treated waste or discharges it to the sanitary sewer. This plant charges $\$ 2-\$ 5 / b b l$. 
The remaining disposal method for solid and oily wastes, salt caverns, appears to be among the least costly off-site disposal options at this time. Disposal at three cavern facilities located in west Texas costs $\$ 1.95-\$ 2.85 / \mathrm{bbl}$. Disposal at the fourth operating disposal cavern, located in east Texas, costs $\$ 6 / \mathrm{bbl}$ or $\$ 50 / \mathrm{yd}^{3}$ for contaminated soils. One reason the salt caverns cost less is that the Railroad Commission of Texas does not yet have regulations specifically targeted at disposal caverns. The four Texas disposal caverns are operating under permits issued by the Commission. However, in April 1996, the Commission proposed draft regulations. Most observers agree that when the regulations become final, the requirements placed on cavern operators will be more stringent than those currently specified by their permits. At that time, cavern siting, operating, monitoring, and closure costs are likely to increase, and the cavern operators will pass the increased costs to their customers. It is not possible to estimate the magnitude of the increase in costs that will follow final cavern disposal regulations.

The costs shown in Tables 8-10 do not include transportation costs, which can be substantial. Limited data collected during the survey indicate that trucking costs are $\$ 42-\$ 63 /$ hour. There are economic incentives for operators to send their wastes to disposal facilities located within a reasonably short distance from the oil and gas production site. Generally, operators will not transport waste more than 50-75 miles unless no other alternatives are available. Although disposal costs are important to an operator when determining which commercial waste disposal company to choose, the total of disposal costs, transportation costs, and other costs weigh heavily in the operator's final decision.

Examination of the data from a geographic perspective provides additional insights into disposal costs. As noted above, the disposal caverns in west Texas are much less costly than the disposal cavern in east Texas. One possible explanation for this cost dichotomy is competition. Figure 4 shows the locations of the four disposal caverns, with 75-mile-radius circles drawn around them. There are no other commercial disposal companies within the 75-mile-radius circle of the east Texas disposal cavern. There are several other commercial disposal companies within the 75-mileradius circle of the three west Texas disposal caverns. All three facilities rank among the lowest-cost facilities for their disposal method.

\subsubsection{Produced Water, Including Rain Water and Other Water-Type Wastes}

Costs for disposing of these wastes are listed in Table 9. Overall, disposal costs are $\$ 0.01$ $\$ 8 / \mathrm{bbl}$, although most are $\$ 0.25-\$ 1.50 / \mathrm{bbl}$. The highest cost, $\$ 8 / \mathrm{bbl}$, is charged at one facility for particularly dirty wastes that need pretreatment before injection. The same facility charges as low as $\$ 0.75 / \mathrm{bbl}$ for cleaner wastes. The lowest cost is charged by a nonprofit facility in California that operates as a cooperative for several member users. 


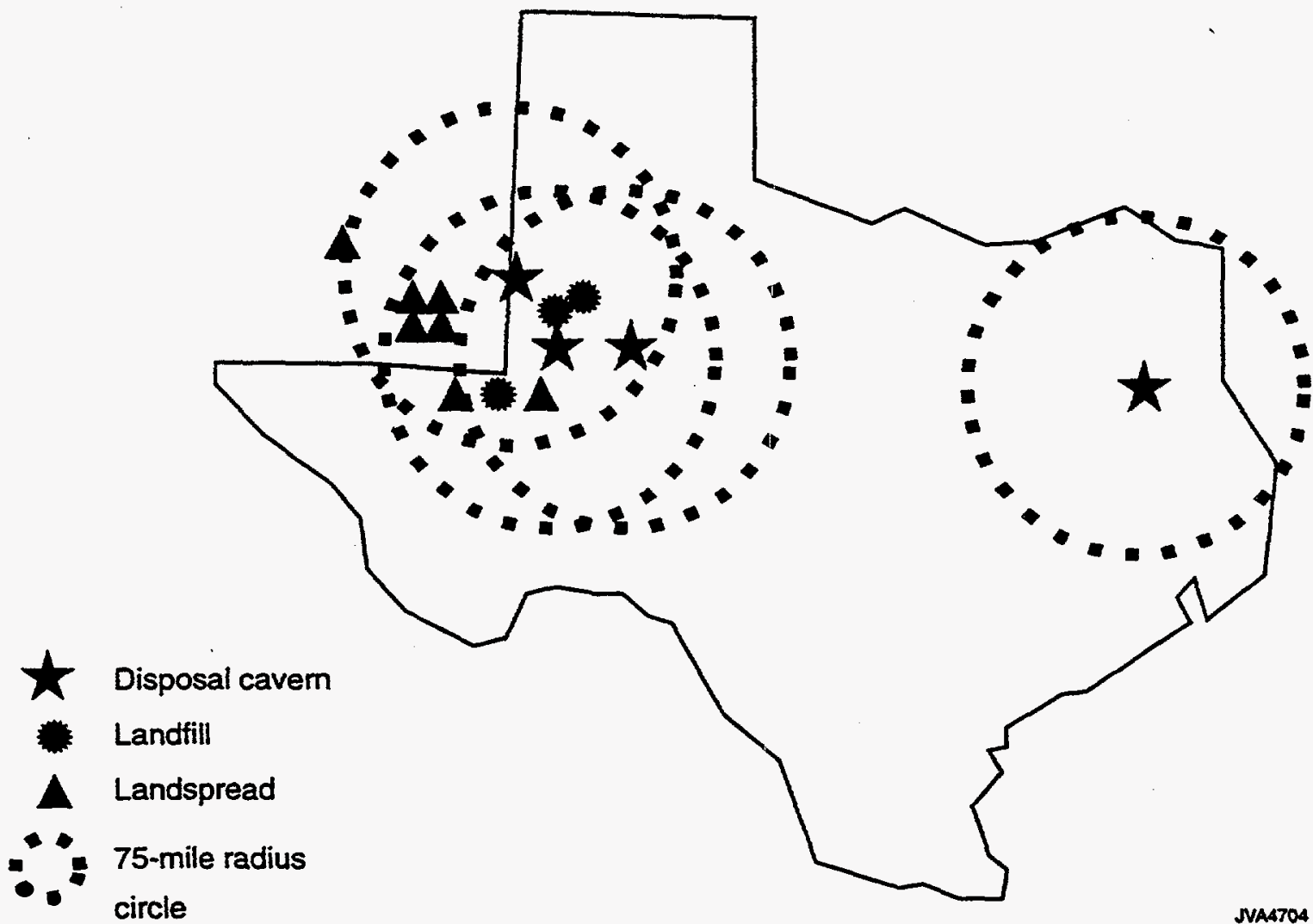

FIGURE 4 Locations of Disposal Caverns and Other Commercial Solid and Oily Waste Disposal Facilities within 75-Mile Radiuses

By far, the most common commercial disposal method for produced water is injection. As mentioned previously, the waste disposal cost survey did not focus on produced water disposal costs, and no attempt was made to obtain costs from most or all commercial produced water disposal companies. The range of costs for injection is the same as that described in the previous paragraph.

Ten companies in Wyoming, five companies in Utah, and four companies in New Mexico use evaporation to dispose of produced water. The cost is $\$ 0.25-\$ 2.50 / \mathrm{bbl}$. Another New Mexico company uses a combination of evaporation and injection, at a cost of $\$ 0.69 / \mathrm{bbl}$. The nonprofit California company described above, which also uses a combination of evaporation and injection, charges $\$ 0.01-\$ 0.09 / \mathrm{bbl}$.

Six companies in Pennsylvania utilize surface water discharge options. Three of these companies treat and blend produced water and discharge it directly through an NPDES permit. Another company treats the waste and discharges it to a sanitary sewer that leads to a municipal wastewater treatment plant. They charge \$1-\$2.10. Two municipal wastewater treatment plants accept water-type wastes but not produced water. They charge $\$ 0.65-\$ 1.50 / \mathrm{bbl}$. Another company, 
in Pennsylvania spreads produced water on roads in the summer and discharges to a municipal wastewater treatment plant in the winter. This company charges $\$ 1.30-4.20 / \mathrm{bbl}$.

Salt caverns have not been used for commercial produced water disposal because they are more costly than the other available produced water disposal options. Caverns are not likely to be used in the future, either, partly because a barrel of brine is brought to the surface for each barrel of produced water that is placed into the cavern. Unless there is a market for the brine, the costs will become prohibitive when compared with those of other locally available options.

\subsubsection{Water-Based Drilling Wastes}

Costs for these wastes are found in Table 8. Overall, disposal costs are $\$ 0.20-\$ 14.70 / \mathrm{bbl}$, $\$ 5-\$ 37.50 / \mathrm{yd}^{3}$ (comparable to $\$ 1.04-\$ 7.80 /$ converted bbl), and $\$ 15-\$ 55 /$ ton (comparable to $\$ 3.93$ $\$ 14.43 /$ converted bbl).

Land spreading appears to be the most common commercial disposal method for waterbased drilling wastes. Prices vary in different states. In Texas, land spreading costs are $\$ 0.20-\$ 7 / \mathrm{bbl}$ and $\$ 5-\$ 10 / \mathrm{yd}^{3}$. In Louisiana, land spreading costs are somewhat higher - \$7.50-\$9.50/bbl. New Mexico's commercial land spreading companies charge $\$ 14-\$ 20 / y d^{3}$. One Wyoming company charges $\$ 50-\$ 55$.

Another common commercial disposal method for water-based drilling waste is disposal pits. Ten Oklahoma pits charge $\$ 0.35-\$ 1.75 / \mathrm{bbl}$, and two Texas pits charge $\$ 1-\$ 2 / \mathrm{bbl}$. Solids are handled at several of the pits; costs are $\$ 5.20-\$ 15 / \mathrm{yd}^{3}$. One Utah pit charges $\$ 1.50 / \mathrm{bbl}$. Seven Wyoming pits charge $\$ 1-\$ 10.50 / \mathrm{bbl}$ and $\$ 37.50 / \mathrm{yd}^{3}$.

Several other commercial disposal companies use a combination of treatment and disposal methods. Five Louisiana facilities and two Texas facilities treat the waste, reuse the solids as landfill cover, and inject the liquid, at a cost of $\$ 7.50 / \mathrm{bbl}$. Two New Mexico companies evaporate the liquids and landfill the solids at a cost of $\$ 2.50-\$ 2.75 / \mathrm{bbl}$ or $\$ 14 / \mathrm{yd}^{3}$ for solids.

Three Pennsylvania companies treat water-based drilling wastes and discharge them to surface waters under an NPDES permit. A fourth company treats the wastes and then discharges them to a local sanitary sewer that leads to a municipal wastewater treatment plant. These companies charge \$2.50-\$14.70/bbl. Two municipal wastewater treatment plants accept water-based drilling wastes and charge $\$ 0.65-\$ 1.50 / \mathrm{bbl}$. A Wyoming company operates a sophisticated industrial wastewater treatment plant that either injects the treated waste or discharges it to the sanitary sewer. This plant charges $\$ 2-\$ 5 / \mathrm{bbl}$. 
One California company treats the wastes and reuses the solids as landfill cover at a cost of $\$ 15-\$ 25 /$ ton.

Salt caverns can be used to dispose of water-based drilling wastes. Cavern disposal costs are $\$ 1.95-\$ 6 / \mathrm{bbl}$. 


\section{CONCLUSIONS}

According to Wakim $(1987,1988)$, in 1985 , the U.S. exploration and production segment of the oil and gas industry generated more than 360 million bbl of drilling wastes, more than 20 billion bbl of produced water, and nearly 12 million bbl of associated wastes. Current exploration and production activities are believed to be generating comparable quantities of waste. Wakim estimates that $28 \%$ of drilling wastes, less than $2 \%$ of produced water, and $52 \%$ of associated wastes are sent to off-site commercial facilities for disposal. Little has been published on the availability of commercial disposal companies in different states. This report provides information on the availability of commercial disposal companies, the treatment and disposal methods they employ, and the amounts they charge. The conclusions are summarized below.

- At the federal level, the majority of oil field wastes are considered to be exempt from the hazardous waste provisions of RCRA. This nonhazardous classification simplifies the disposal of oil field waste and allows for reduced disposal costs. All oil- and gas-producing states except California accept this nonhazardous classification. California tests each waste for hazardous characteristics; if the waste fails, it is considered hazardous.

- Oil field wastes are regulated at the state level. All oil- and gas-producing states allow some on-site disposal of oil field wastes. Commonly used methods include underground injection, on-site burial, land spreading or other land treatment, evaporation, surface discharge, and recycling.

- Many drilling wastes and associated wastes are sent to off-site commercial disposal facilities. Interviews with oil and gas officials in 31 oil- and gasproducing states suggest that there are two off-site disposal trends.

1. Nine states contain numerous commercial disposal companies dedicated to handling only oil field wastes. These companies use the same disposal methods as those used for on-site disposal. In addition, the Railroad Commission of Texas has issued permits allowing several salt caverns to be used for disposal of oil field wastes.

2. Twenty-two other oil- and gas-producing states contain few or no disposal companies dedicated to oil and gas industry waste. The only off-site commercial disposal companies available are general industrial waste disposal facilities or sanitary landfills. 
- The cost of off-site commercial disposal varies, depending on the disposal method used, the state in which the disposal company is located, and the degree of competition in the area.

- In most cases, companies can dispose of their oil field wastes at a lower cost on-site than off-site and therefore choose on-site disposal. When wastes must be sent off-site for regulatory, economic, or other reasons, operators closely examine the total cost of off-site disposal. The total cost includes transportation and vehicle washout costs as well as disposal costs.

- Disposal caverns are presently cost-competitive in the Texas waste disposal market. However, disposal cavem costs are likely to increase in the near future as the Railroad Commission of Texas adopts regulations governing cavern disposal. It is unclear how the increased costs will affect the competitiveness of disposal caverns in the future, since costs at competing waste disposal facilities are likely to change.

- Regulatory officials in Louisiana, New Mexico, and Mississippi are presently considering how to manage cavern disposal in their states. The use of caverns to dispose of oil field waste will spread to other states, depending on the availability of suitable salt formations and the size of the off-site commercial disposal market in those states. The market, in turn, is affected by the stringency of state regulations on disposal of oil field wastes. Thus, future changes to state oil field waste disposal regulations will be an important catalyst to encourage new cavern disposal operations.

- This report does not evaluate the economic feasibility of using salt caverns to dispose of oil field wastes on-site. The author is not aware of any U.S. proposals to operate on-site disposal caverns, but one such project for Husky Oil in Saskatchewan, Canada, to dispose of its own wastes has been approved. 


\section{REFERENCES}

API, 1994, "Design of Solution-Mined Underground Storage Practices," Recommended Practice 1114, American Petroleum Institute, Washington, D.C., June.

CSA, 1993, "Storage of Hydrocarbons in Underground Formations - Oil and Gas Industry Systems and Materials," Standard Z341-93, Canadian Standards Association, Rexdale, Ontario, Canada, July.

DOE/OGCC, 1993, Oil and Gas Exploration and Production Waste Management: A 17-State Study, DOE/FE-62017-H1, prepared by ICF Resources, Inc., Washington, D.C., for U.S. Department of Energy, Washington, D.C., and Interstate Oil and Gas Compact Commission, Oklahoma City, Okla., June.

EPA, 1994, Associated Waste Report: Crude Oil Tank Bottoms and Oily Debris, draft, U.S. Environmental Protection Agency, Washington, D.C., March.

IOGCC, 1994, IOGCC Environmental Guidelines for State Oil \& Gas Regulatory Programs, Interstate Oil and Gas Compact Commission, Oklahoma City, Okla., May.

IOGCC, 1995, Natural Gas Storage in Salt Caverns - A Guide for State Regulators, Interstate Oil and Gas Compact Commission, Oklahoma City, Okla., Oct.

Johnson, K.S., and S. Gonzales, 1978, Salt Deposits in the United States and Regional Geologic Characteristics Important for Storage of Radioactive Wastes, Y/OWISUB-7414/1, prepared by Earth Resources Associates, Inc., Athens, Ga., for U.S. Department of Energy, Office of Waste Isolation, March.

Querio, C.W., 1980, "Design and Construction of Solution-Mined Caverns for LPG Storage," presented at Solution Mining Research Institute's fall meeting, Minneapolis, Minn., Oct. 12-15.

Veil, J. et al., 1996, Preliminary Technical and Legal Evaluation of Disposing of Nonhazardous Oil Field Waste into Salt Caverns, prepared by Argonne National Laboratory, Washington, D.C., for the U.S. Department of Energy, June.

Wakim, P.G., 1987, API 1985 Production Waste Survey, Statistical Analysis and Survey Results, American Petroleum Institute, Washington, D.C., Oct.

Wakim, P.G., 1988, API 1985 Production Waste Survey, Part II-Associated and Other Wastes, Statistical Analysis and Survey Results, American Petroleum Institute, Washington, D.C., June. 